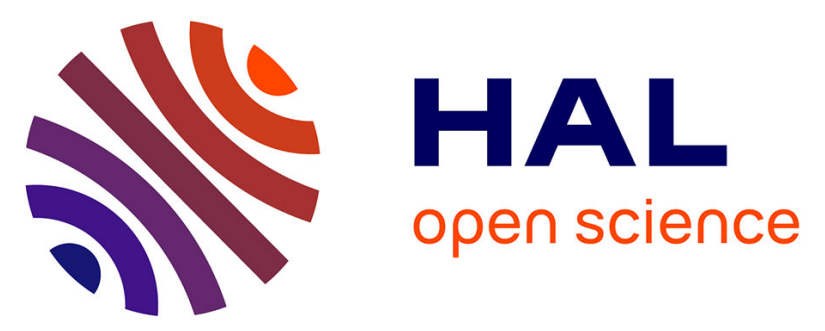

\title{
A comparative transmission electron microscopy study of titanium dioxide and carbon black nanoparticles uptake in human lung epithelial and fibroblast cell lines.
}

Esther Belade, Lucie Armand, Laurent Martinon, Laurence Kheuang, Jocelyne Fleury-Feith, Armelle Baeza-Squiban, Sophie Lanone, Marie-Annick Billon-Galland, Jean-Claude Pairon, Jorge Boczkowski

\section{To cite this version:}

Esther Belade, Lucie Armand, Laurent Martinon, Laurence Kheuang, Jocelyne Fleury-Feith, et al.. A comparative transmission electron microscopy study of titanium dioxide and carbon black nanoparticles uptake in human lung epithelial and fibroblast cell lines.. Toxicology in Vitro, 2012, 26 (1), pp.57-66. 10.1016/j.tiv.2011.10.010 . inserm-00673352

\section{HAL Id: inserm-00673352 https://www.hal.inserm.fr/inserm-00673352}

Submitted on 23 Feb 2012

HAL is a multi-disciplinary open access archive for the deposit and dissemination of scientific research documents, whether they are published or not. The documents may come from teaching and research institutions in France or abroad, or from public or private research centers.
L'archive ouverte pluridisciplinaire HAL, est destinée au dépôt et à la diffusion de documents scientifiques de niveau recherche, publiés ou non, émanant des établissements d'enseignement et de recherche français ou étrangers, des laboratoires publics ou privés. 


\title{
A Comparative Transmission Electron Microscopy Study of Titanium Dioxide and Carbon Black Nanoparticles Uptake in Human Lung Epithelial and Fibroblast Cell Lines
}

\author{
Esther Belade ${ }^{a, b, c}$, Lucie Armand ${ }^{a, b, c}$, Laurent Martinon ${ }^{d}$, Laurence Kheuang ${ }^{a, b, c}$, \\ Jocelyne Fleury-Feith ${ }^{e}$, Armelle Baeza-Squiban $^{\dagger}$, Sophie Lanone ${ }^{a, b, c}$, \\ Marie-Annick Billon-Galland ${ }^{d}$, Jean-Claude Pairon ${ }^{\mathrm{a}, \mathrm{b}, \mathrm{c}, \mathrm{g}, *}$, Jorge Boczkowski ${ }^{\mathrm{a}, \mathrm{b}, \mathrm{c}, \mathrm{g}, *}$
}

a: INSERM, U955, Créteil, F-94000, France

b: University Paris Est, Faculté de médecine, Créteil, F-94000, France

C: AP-HP, Hôpital H. Mondor - A. Chenevier, Service hospitalier, Créteil, F-94000, France

d: Laboratoire d'Etude des Particules Inhalées, Department of Paris, 11 rue George Eastman, Paris, F-75013, France

e: Service d'Histologie et Biologie Tumorale, Hôpital Tenon, 4 rue de la Chine, Paris, F75020, France, and University Pierre et Marie Curie, Paris, F-75005, France

f: University Paris Diderot Sorbonne Paris Cité, Unit of Functional and Adaptive Biology (BFA), Laboratory of Molecular and Cellular Responses to Xenobiotics, CNRS EAC 7059, Paris, F-75013, France

g: Hôpital Intercommunal de Créteil, Service de pneumologie et pathologie professionnelle, Créteil, F-94000, France

${ }^{*}$ equal contribution

Correspondance:

Esther Belade, PhD student Unité Inserm 955, Equipe 4

Faculté de Médecine de Créteil 8 rue du Général Sarrail 94000 Créteil phone: +331 49813606

fax : +331 49813725

mail: esther.belade@orange.fr 


\begin{abstract}
Several studies suggest that the biological responses induced by manufactured nanoparticles (MNPs) may be linked to their accumulation within cells. However, MNP internalisation has not yet been sufficiently characterised. Therefore, the aim of this study was to compare the intracellular uptake of 3 different MNPs: two made of carbon black (CB) and one made of titanium dioxide $\left(\mathrm{TiO}_{2}\right)$, in 16HBE bronchial epithelial cells and MRC5 fibroblasts. Transmission electron microscopy was used to evaluate the intracellular accumulation. Different parameters were analysed following a time and dose-relationship: localisation of MNPs in cells, percentage of cells having accumulated MNPs, number of aggregated MNPs in cells, and the size of MNP aggregates in cells. The results showed that MNPs were widely and rapidly accumulated in 16HBE cells and MRC5 fibroblasts. Moreover, MNPs accumulated chiefly as aggregates in cytosolic vesicles and were absent from the mitochondria or nuclei. $\mathrm{CB}$ and $\mathrm{TiO}_{2} \mathrm{MNPs}$ had similar accumulation patterns. However, $\mathrm{TiO}_{2}$ aggregates had a higher size than CB aggregates. Intracellular MNP accumulation was dissociated from cytotoxicity. These results suggest that cellular uptake of MNPs is a common phenomenon occurring in various cell types.
\end{abstract}

Keywords: nanotechnologies; nanomaterials; toxicity; lung 


\section{Introduction}

Nanotechnology is an emerging field involving a wide range of technologies that measure, manipulate, or incorporate materials having at least one dimension between 1 and 100 nanometers (ASTM International, 2006). Manufactured nanoparticles (MNPs) are intentionally produced for use in various consumer products or industrial techniques (e.g., as pigments or chemical catalysts). The properties of nanoparticles differ from those of bulk materials of the same compound, allowing them to exert novel physical and chemical functional activities (Lanone et al., 2006, 2009; Oberdörster et al., 2005a).

Although new applications of MNPs are generating considerable enthusiasm, there is increasing evidence that MNP exposure can lead to adverse health effects. The respiratory system is a major route of unintentional exposure to aerosolised MNPs. Moreover, the respiratory system is a potential route for MNP translocation to the systemic circulation. However, MNP translocation studies showed that this was a limited phenomenon, the pulmonary retention being more important (Kreyling et al., 2002). Therefore, MNP toxicological studies have been widely focused on the MNP fate in the pulmonary system. In vitro and in vivo studies established that MNP exposure can alter cell viability, induce inflammation and pulmonary tissue remodelling, and impair redox regulation (Donaldson et al., 2005; Stone et al., 2007). Furthermore, several studies suggest that the biological responses induced by MNPs may be linked to MNP accumulation within cells (Bartneck et al., 2010; Oh et al., 2010). Indeed, internalised MNPs may directly target organelles such as the mitochondria, leading to oxidative stress (Li et al., 2003; Oberdörster et al., 2005a). Another target of MNPs is the nucleus: thus, MNPs can directly or indirectly induce DNA oxidative damages in the nuclear compartment (Bhattacharya et al., 2009; Mroz et al., 2007; Trouiller et al., 2009). However, MNP internalisation has not yet been sufficiently characterised.

Various techniques have been used to study MNP internalisation. Flow cytometry or confocal microscopy was used in recent studies (Faklaris et al., 2008; Thurn et al., 2010). However, these techniques require MNP labeling or surface modification, which may constitute a major disadvantage given that changes in MNP physical characteristics (size, shape, surface chemistry) can modify the internalisation and/or subcellular localisation of MNPs (Al-Rawi et al., 2011; Gupta et al., 2005; Nativo et al., 2008; Win et al., 2005). Transmission electron microscopy (TEM) is the technique of reference for studying MNP internalisation. With TEM, nano-sized structures can be identified in the cell environment and within cellular organelles (Oberdörster et al., 2005b). However, TEM has rarely been used to 
accurately quantify MNP internalisation. TEM evaluation of internalisation is a cumbersome and expensive procedure and requires optimal sample preparation (Schrand et al., 2010). To the best of our knowledge, no comparative TEM studies of the internalisation of various MNPs by various cell types are available. Moreover, the relationship between MNP internalisation and their physico-chemical characteristics has been insufficiently analysed.

Therefore, the aim of this study was to use TEM to compare the intracellular uptake of 3 well-characterized MNPs (one made of titanium dioxide and two of carbon black) in 2 different relevant target cells (one representative of the bronchial epithelium, the other of the underlying connective tissue), according to MNP concentration and time of exposure. This comparison was supported by several parameters (localisation of aggregated MNPs in cells, percentage of cells having accumulated MNPs, number of aggregated MNPs in cells, size of MNP aggregates in cells analysed at different time points). Furthermore, we examined the effects of MNPs on cell viability.

We choose titanium dioxide $\left(\mathrm{TiO}_{2}\right)$ and carbon black (CB) MNPs because $\mathrm{TiO}_{2}$ and CB nanoparticles are among the most widely produced nanomaterials (Baan et al., 2006). $\mathrm{TiO}_{2}$ in particles of supra-nanometer scale has been used commercially for over 100 years as a white pigment in numerous products including paints and other coatings, foods, cosmetics, and skin-care preparations such as topical sunscreens. Several newer technologies use $\mathrm{TiO}_{2}$ MNPs, for instance for producing paints and sunscreen lotions/sprays. CB MNPs are used chieftly as a pigment in inks and paints and in automobile tires (Donaldson et al., 2005; Ema et al., 2010).

\section{Material and methods}

\subsection{Cellular models}

MRC5 cells (ATCC CCL-171), a human fibroblast cell line, and the 16HBE140bronchial cell line (provided by Dr. D.C. Gruenert; Medical Research Facility, California Pacific Medical Centre, San Francisco, CA, USA) were used in this study. MRC5 cells were derived from normal lung tissue of a 14-week-old male foetus (Jacobs et al., 1970). The 16HBE140- cell line was originally developed from human bronchial epithelium, transformed with SV40 large T-antigen (Cozens et al., 1994). Both cell lines were maintained in a culture medium (DMEM for MRC5 and DMEM/F12 for 16HBE140-) with L-Glutamine supplemented with $10 \%$ foetal bovine serum (FBS) for MRC5 cells, $2 \%$ Ultroser G (UG) for $16 \mathrm{HBE}$ cells and $1 \%$ antibiotics at $37^{\circ} \mathrm{C}$ in a $5 \%-\mathrm{CO}_{2}$ humidified incubator. These cells were seeded at a density of 1 to $1.6 \times 10^{4}$ cells.cm². 


\subsection{Manufactured nanoparticles}

Three types of MNPs were tested: two made of CB (CB21 [P60] and CB13 [FW2] from Evonik/Degussa, Essen, Germany) and one of $\mathrm{TiO}_{2}$ (637254 from Sigma-Aldrich, Saint Louis, MO, USA). The mean aerodynamic diameters reported by the suppliers were 21 and $13 \mathrm{~nm}$ for the CB21 and CB13 MNPs, respectively, and $15 \mathrm{~nm}$ for $\mathrm{TiO}_{2} \mathrm{MNPs}$.

Dry powders were used to evaluate the physico-chemical characteristics of MNPs. Specific surface area was measured at $-196^{\circ} \mathrm{C}$ using the nitrogen absorption-desorption technique (Brunauer Emmet Teller method, BET). MNP granulometry and aggregation status were evaluated in particle suspensions using photon correlation spectroscopy (PCS) and zeta potential measurement, respectively (Zetasizer 300HS, Malvern Instruments, Malvern, UK).

Stock suspensions of MNPs were prepared by weighing out the dry powders and then suspending them in serum-free $(0 \%)$ culture medium to reach the concentration of $2 \mathrm{mg}^{-\mathrm{ml}^{-1}}$. The stock suspensions were stored at $-20^{\circ} \mathrm{C}$. Ten minutes before starting the experiments, we sonicated the defrosted MNP stock suspensions in an ultrasound bath to achieve optimal dispersion. We then diluted the suspensions in serum-free culture medium by successive dilutions. Cells were exposed to MNP concentrations of $0.5,5$ and $10 \mu \mathrm{g} . \mathrm{cm}^{-2}$ (of cultured surface) for 6, 24 and 48 hours. Given that cells were cultured in $75 \mathrm{~cm}^{2}$ flasks containing 15 $\mathrm{ml}$ of DMEM, we needed suspensions to be diluted at the doses of $2.5,25$ and $50 \mu \mathrm{g} \cdot \mathrm{ml}^{-1}$ (corresponding to $0.5,5$ and $10 \mu \mathrm{g} . \mathrm{cm}^{-2}$ ). To do that, the stock suspensions were first diluted at $1: 4$, then a second dilution (1: 10) was made from the new suspension to reach the concentration of $50 \mu \mathrm{g} \cdot \mathrm{ml}^{-1}$ (or $10 \mu \mathrm{g} . \mathrm{cm}^{-2}$ ). Finally, the suspensions of 0.5 and $5 \mu \mathrm{g} . \mathrm{cm}^{-2}(2.5$, $25 \mu \mathrm{g} \cdot \mathrm{ml}^{-1}$ ) were done by diluting the $10 \mu \mathrm{g} \cdot \mathrm{cm}^{-2}$ MNP suspension.

MNP endotoxin content was measured using the Limulus Amebocyte Lysate (LAL) kit QCL-1000 (Lonza, Basel, Switzerland). Briefly, particles in DMEM were sonicated (as described above), and the particle suspensions were centrifuged for $10 \mathrm{~min}$ at $18,000 \mathrm{~g}$. The supernatants were collected and centrifuged. This sequence was repeated twice and the endotoxin levels in the supernatants were then determined.

The main physico-chemical characteristics are summarized in Table 1.

\subsection{Cytotoxicity assay}

Cytotoxicity was assessed using the colorimetric WST-1 assay (Roche Diagnostics, Rotkreuz, Switzerland), which measures the mitochondrial dehydrogenase activity in viable 
cells. MRC5 and 16HBE cells were seeded in 96-well microplates at a density of $1.6 \mathrm{x}$ $10^{4}$ cells $/ \mathrm{cm}^{2}$ in DMEM containing $10 \%$ FBS or $2 \%$ UG, then left in the medium for $24 \mathrm{~h}$. Shortly before starting the exposures, $10 \mu \mathrm{g} . \mathrm{cm}^{-2}$ of each MNP suspension were prepared as described above. However, since surfaces $\left(0.32 \mathrm{~cm}^{2}\right)$ and volumes $(200 \mu \mathrm{l})$ in microplate wells were different from those in flasks, to expose cells to the same MNP concentration, the doses were adapted considering that $10 \mu \mathrm{g} \cdot \mathrm{cm}^{-2}$ corresponded to $16 \mu \mathrm{g} \cdot \mathrm{ml}^{-1}$ of MNPs. After removing DMEM from wells and washing cells with $100 \mu \mathrm{l} /$ well of phosphate buffered saline (PBS), MNP suspensions were distributed in each well. After $24 \mathrm{~h}$ of contact, MNP suspensions were removed and cells were washed with PBS. Then, cells were incubated with $100 \mu \mathrm{l} /$ well of WST- 1 solution for $2 \mathrm{~h}$, at $37^{\circ} \mathrm{C}$, in the dark. Two hours later, the cytotoxicity was determined by measuring the absorbance with a scanning multi-well spectrophotometer (Multiskan Ex microplate photometer, ThermoFisher Scientific, Waltham, MA, USA). The absorbance directly correlates to the number of viable cells. Three independent experiments were performed with 3 replicate wells used for each condition in each experiment.

\subsection{Transmission electron microscopy}

\subsubsection{Cell pellet fixation}

Following exposure of cells to MNPs in flasks, attached cells were washed with culture media and fixed in situ with $2.5 \%$ glutaraldehyde in $0.045 \mathrm{M}$ sodium cacodylate buffer $(\mathrm{pH} 7.4)$ at $4^{\circ} \mathrm{C}$ for 2 hours. The cells were then washed 3 times in sodium cacodylate buffer. Once recovered by de-adhering with scrapers, cell suspensions in $0.045 \mathrm{M}$ sodium cacodylate buffer were centrifugated at $1500 \mathrm{rpm}$ for 5-7 $\mathrm{min}$, and the pellets were post-fixed with $2 \%$ osmium tetroxide in distilled water for $30 \mathrm{~min}$, at room temperature and in the dark.

\subsubsection{Cell pellet embedding}

The post-fixed pellets were dehydrated in graded ethanol series before being transferred into Beem capsules filled with epon resin (48.9\%), dodecenyl succinic anhydride $(17.9 \%)$ and nadic methyl anhydride (33.3\%). Then, the capsules were incubated at $37^{\circ} \mathrm{C}$, in an oven vacuum for $24 \mathrm{~h}$, followed by incubation in a $60^{\circ} \mathrm{C}$ oven for $24 \mathrm{~h}$, to complete the embedding.

\subsubsection{Sample ultrathin cuts and staining}

Ultrathin sections (60 $\mathrm{nm}$ thickness) were made with a Leika ultramicrotome and transferred without contrasting onto copper grids, they were observed with an analytical 
transmission electron microscope (TEM).

\subsubsection{TEM evaluation}

The microscope used for the study was a JEOL 1200 EX II TEM at 60kV (JEOL, Tokyo, Japan), fitted out with an energy dispersive X-ray spectrometer (EDS OXFORD LINK ISIS 300 spectrometer) and a digital GATAN camera (ERLANGSHEN ES500W). Observed MNPs were classified as aggregated within cells. We defined an MNP aggregate as a cluster of more than 1 MNP (Hackley, 2001).

Measurements were made on 50 morphologically preserved cells chosen randomly from 5 different grids in each condition. Observations were performed by 2 different observers, between whom agreement was greater than $95 \%$. The following parameters were calculated using the SAISAM software (MicroVision, Evry, France):

1. Cell localisation of MNPs (free in the cytoplasm or in vacuoles, mitochondria, or nuclei)

2. Percentage of cells containing MNPs

3. Mean number of aggregated MNPs in cells (per cell)

4. Mean size of intracellular MNP aggregates (per cell)

4.1. Mean size of each aggregate

4.2. Percentage of cell surface area occupied by MNP aggregates

To improve the accuracy of our estimate of intracellular MNP accumulation, each cell displaying morphological signs of cellular death (cellular membrane disruption, cellular splitting/blebbing) was systematically excluded. Thus, only cells with visible and well preserved cytoplasm, nucleus, and mitochondria were studied. Furthermore, the chemical nature of $\mathrm{TiO}_{2}$ MNPs was checked using EDX analysis. Aggregated MNPs were classified based on their subcellular localisation (free in cytoplasm or in vacuoles, mitochondria, or nuclei). The time-response relationship was examined after 6, 24 and $48 \mathrm{~h}$ exposure to 5 $\mu \mathrm{g} . \mathrm{cm}^{-2}$ and the dose-response relationship was investigated after $24 \mathrm{~h}$ of contact to $0.5,5$ and $10 \mu \mathrm{g} \cdot \mathrm{cm}^{-2}$ of MNPs.

\subsection{Statistical analysis}

Three independent experiments were performed by exposing the cells to the different MNPs at the different doses and during the different time periods. In the TEM studies, we analysed 50 cells of each experiment. We compared MNP accumulation across doses and 
exposure times using the Chi-2 test and the other parameters using one-way ANOVA. When ANOVA showed statistically significant differences between treatments $(p<0.05)$, pairwise comparisons were performed using Tukey's test. The cellular viability data were compared by performing a Kruskal-Wallis test, followed by a Dunn's test. All statistical analyses were conducted using GraphPad Prism software (GraphPad Software, Inc., La Jolla, CA, USA). $p<0.05$ was considered statistically significant.

\section{Results}

\subsection{Physico-chemical characterisation of MNPs}

Table 1 shows the physico-chemical characteristics of the MNPs. The 3 types of MNP had similar sizes and a round-like shape (L'Azou, 2008). Furthermore, CB13 MNPs had a significantly larger specific surface area than CB21 MNPs. The 3 MNPs shared a tendency to form aggregates of around $1 \mu \mathrm{m}$ in the culture media, the CB21 aggregates being significantly larger than the $\mathrm{TiO}_{2}$ aggregates. No endotoxin contamination was detected in any of the three MNP samples.

\subsection{Cell localisation of MNP}

Figures 1 and 2 show typical TEM images of MRC5 and 16HBE cells exposed to 5 $\mu \mathrm{g} . \mathrm{cm}^{-2}$ of $\mathrm{CB} 13, \mathrm{CB} 21$ or $\mathrm{TiO}_{2}$ MNP for 6 hours. The results of MRC5 exposure to $5 \mu \mathrm{g} . \mathrm{cm}^{-2}$ of MNPs are shown in figure 1. Panel A illustrates the CB13 MNP distribution in a MRC5 cell. CB13 MNPs were found as aggregates in the cytosol, usually in vesicle-like compartments and in rare instances free in the cytoplasm, being impossible to quantify such rare events. No particles were seen in the mitochondria, nuclei, or other organelles. Panels $B$ and $C$ of figure 1 show $\mathrm{CB} 21$ and $\mathrm{TiO}_{2}$ MNP accumulation in the MRC5 cell line. Both MNP types were also found as aggregates in cytosolic vesicles. Panels $A, B$ and $C$ of figure 2 display the distributions of the 3 MNPs in 16HBE bronchial cells. As previously described in MRC5 cells, each MNP type was usually seen as aggregates in cytoplasmic vesicles and less often visualised free in the cytosol. Again, no MNPs were found in mitochondria or nuclei.

\subsection{Percentage of cells containing MNPs}

Figure 3 shows the percentages of the 2 cell lines containing the three MNPs.

\section{$\underline{\text { Time-response relationship }}$}

About $60 \%$ of MRC5 cells contained CB13 MNPs after $6 \mathrm{~h}$ (Fig. 3A). This percentage increased to nearly $80 \%$ after $24 \mathrm{~h}$ ( $p<0.05$ vs. $6 \mathrm{~h}$ ) then remained stable until $48 \mathrm{~h}$. Moreover, 
the percentage of cells containing $\mathrm{TiO}_{2}$ and $\mathrm{CB} 21$ MNPs also increased significantly over time.

Almost $95 \%$ of $16 \mathrm{HBE}$ cells accumulated CB13 MNPs after $6 \mathrm{~h}$ and this value did not change over 24 and 48h (Fig. 3B). An absence of time-response effect was also observed with $\mathrm{TiO}_{2}$ MNPs. Moreover, the percentage of cells containing MNPs after $6 \mathrm{~h}$ was significantly lower with $\mathrm{TiO}_{2}$ and CB21 MNPs than with CB13 MNPs $(p<0.05)$.

Finally, with 16HBE cells, the percentage of cells containing CB13 and CB21 MNPs at $6 \mathrm{~h}$ was significantly higher than MRC5 cells $(p<0.05)$.

\section{Dose response relationship}

About $60 \%$ of MRC5 cells contained CB13 MNPs after exposure to $0.5 \mu \mathrm{g} . \mathrm{cm}^{-2}$ (Fig. $3 C)$. This percentage increased to near $80 \%$ when cells were exposed to $5 \mu \mathrm{g} \cdot \mathrm{cm}^{-2}(p<0.05$ vs. $0.5 \mu \mathrm{g} . \mathrm{cm}^{-2}$ ) and no further increase was observed after exposure to $10 \mu \mathrm{g} \cdot \mathrm{cm}^{-2}$. Similar results were obtained with CB21 MNPs. A slightly different response was observed after exposure to $\mathrm{TiO}_{2}$ MNPs, since the percentage increased significantly after exposure to 5 $\mu \mathrm{g} . \mathrm{cm}^{-2}$ compared to $0.5 \mu \mathrm{g} . \mathrm{cm}^{-2}$ and then decreased when a dose of $10 \mu \mathrm{g} . \mathrm{cm}^{-2}$ was used.

Almost $80 \%$ of $16 \mathrm{HBE}$ cells accumulated CB13 MNPs after exposure to $0.5 \mu \mathrm{g} . \mathrm{cm}^{-2}$ and this value did not change when doses of 5 and $10 \mu \mathrm{g} \cdot \mathrm{cm}^{-2}$ were used (Fig. 3D). A similar response was observed with $\mathrm{TiO}_{2}$ MNPs. However, with CB21 MNPs, the percentage of cells containing MNPs increased dose-dependently between 5 and $10 \mu \mathrm{g} . \mathrm{cm}^{-2}(p<0.05$ in both cases). Moreover, the percentage of cells containing MNPs after exposure to $0.5 \mu \mathrm{g} . \mathrm{cm}^{-2}$ was significantly lower with $\mathrm{TiO}_{2}$ and CB21 MNPs than with $\mathrm{CB} 13$ MNPs $(p<0.05)$.

No significant difference in the dose-response effect was found between the 2 cell lines, except for CB13 accumulation that seemed to occur in more 16HBE cells with the lowest dose.

Overall, these results show time- and dose-dependent modulations in the percentage of MRC5 cells containing the three MNPs. These modifications were not found consistently with $16 \mathrm{HBE}$ cells.

\subsection{Mean number of aggregated MNPs in cells}

Figure 4 shows the average number of aggregated MNPs observed in both cell lines. Indeed, as accumulated MNPs were found chiefly as aggregates in both cell types, we 
therefore counted only MNP aggregates.

\section{$\underline{\text { Time-response relationship }}$}

With MRC5 cells, we found a time-dependent increase in the number of CB13 MNP aggregates but not in the number of $\mathrm{CB} 21$ and $\mathrm{TiO}_{2}$ MNPs (Fig. 4A). By contrast, a timedependent modification in the number $\mathrm{CB} 21$ and $\mathrm{TiO}_{2}$ MNPs aggregates was observed in 16HBE cells (Fig. 4B). In neither cell type were there any major differences across the 3 MNP types. Finally, differences were found between the MNP aggregate numbers in 16HBE and MRC5 cells after $6 \mathrm{~h}$ but not after $24 \mathrm{~h}$ or $48 \mathrm{~h}$.

\section{Dose response relationship}

A dose-response effect was observed for the 3 MNPs in MRC5 cells (Fig. 4C). With

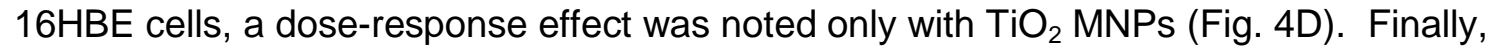
$16 \mathrm{HBE}$ cells contained larger aggregate numbers of CB13 and CB21 MNPs at $0.5 \mu \mathrm{g} . \mathrm{cm}^{-2}$ than did MRC5 cells $(p<0.05)$.

\subsection{Mean size of intracellular MNP aggregates}

\subsubsection{Mean size of individual aggregates (Fig. 5).}

Figure 5 shows the mean size of individual MNP aggregates observed in both cell lines. As we performed these observations by TEM, a two-dimensional technique, the aggregate size was expressed as a surface $\left(\mu \mathrm{m}^{2}\right)$.

\section{$\underline{\text { Time-response relationship }}$}

In MRC5 cells, the mean size of individual CB13 and CB21 MNP aggregates increased transiently at $24 \mathrm{~h}$ (Fig. $5 \mathrm{~A}$ ). After $6 \mathrm{~h}$, the mean size was significantly greater for $\mathrm{TiO}_{2}$ MNP aggregates than for CB13 and CB21 MNP aggregates (6 fold increase, $p<0.05$ for both comparisons) and did not change significantly over time. A similar general pattern was observed in 16HBE cells (Fig. 5B) except that the transient increase was noted only with $\mathrm{TiO}_{2}$ MNPs. No major differences were found between the 2 cell lines.

\section{Dose response relationship}

The size of MNP aggregates showed no major dose-dependency with either cell line (Fig. 5C and 5D). In both cell lines, the size with exposure to $0.5 \mu \mathrm{g} . \mathrm{cm}^{-2}$ was higher with $\mathrm{TiO}_{2}$ MNPs than with the other 2 MNPs ( $p<0.05$ for both comparisons). The size was greater 
in $16 \mathrm{HBE}$ cells than in MRC5 cells.

3.5.2. Percentage of cell surface area occupied by MNP aggregates (Fig. 6).

As compared to the size of individuals MNP aggregates, similar time- and dosedependencies of aggregate size were obtained when the results were expressed as the percentage of the cell surface area occupied by MNP aggregates on TEM sections (Fig. 6).

\subsection{Cytotoxicity of MNPs in MRC5 and 16HBE cell lines}

Figure 7 shows the percentage of viable MRC5 and 16HBE cells after 24h exposure to each MNP in a dose of $10 \mu \mathrm{g} . \mathrm{cm}^{-2}$.

After $24 \mathrm{~h}$ of exposure to $10 \mu \mathrm{g} . \mathrm{cm}^{-2}$ of CB13 MNPs, the percentage of viable MRC5 cells decreased significantly to about $30 \%$. No changes in $16 \mathrm{HBE}$ cell viability were noted under the same conditions. Furthermore, the viability of MRC5 and 16HBE cells did not change after exposure to $\mathrm{CB} 21$ and $\mathrm{TiO}_{2}$ MNPs.

\section{Discussion}

The main results of our study are as follows: 1) MNP accumulation occurred in a high percentage of cells overall $(60-80 \%)$, was close to the peak value after only $6 \mathrm{~h}$, and occurred even with the lowest dose of $0.5 \mu \mathrm{g} . \mathrm{cm}^{-2}$; 2) MNPs accumulated chiefly as aggregates in cytosolic vesicles, and the number of aggregates increased over time or with the dose, except with CB MNPs in 16HBE cells whose aggregate number was at the peak after $6 \mathrm{~h}$ (CB13) or with the lowest dose studied (CB13 and CB21); and 3) with the shortest exposures and lowest doses, the size was higher overall for $\mathrm{TiO}_{2} \mathrm{MNP}$ aggregates than for the $2 \mathrm{CB}$ MNP aggregates. Although several statistically significant differences between the 2 cell lines were found, these differences were quantitatively minor, indicating that the behaviour of the 2 cell lines was similar overall after exposure to all 3 MNP types. Thus, intracellular MNP accumulation seems to be a common and rapid phenomenon that occurs in both epithelial and mesenchymal cells. However, the chemical nature of the MNPs influences intracellular accumulation. Thus, compared to the $2 \mathrm{CB}$ MNP types, $\mathrm{TiO}_{2} \mathrm{MNPs}$ had a larger mean aggregate size within cells and a smaller specific surface area and aggregate size in the culture media (Table 1). Finally, MNP accumulation was dissociated from cellular toxicity. Indeed, CB13 was the only cytotoxic MNP type, and this cytotoxicity occurred only with the MRC5 cells.

The first aim of the study was to compare MNP accumulation in different cell types. 
Since the respiratory system is a major route of MNP entry into the body, we used $16 \mathrm{HBE}$ and MRC5 cells as models of the bronchial epithelium and subjacent connective tissue, respectively. It is reasonable to use TEM to confirm cellular uptake of MNPs, TEM being a good qualitative method to analyse particle uptake. However, because any TEM picture is only reflecting one plane of cells, this technique is considered at most as a semiquantitative method to determine the MNP distribution in a whole cell. Therefore, to obtain reproducible and representative results, 50 cells on several different fields were observed and each entire cell was examined. In both cell types, MNPs accumulated rapidly, in more than half the cultured cells, but occupied a small percentage of the cell surface area (between 0.04 and $4 \%$ ). Furthermore, in both cell types, invaginations of the plasmic membrane were observed and MNPs were found chiefly as aggregates located in cytosolic vesicles. These observations suggest an endocytosis-mediated mechanism of internalisation, as described previously (Faklaris et al., 2009; Saxena et al., 2008; Singh et al., 2007; Stearns et al., 2001; Thurn et al., 2010). In these studies, various endocytic pathways have been suspected to be involved in MNP accumulation (e.g., macropinocytosis, clathrin-mediated endocytosis, or caveolae-mediated endocytosis). The results showed that macropinocytosis seemed to be the principal mechanism of MNP uptake. Our observations are in agreement with these results. Indeed, membrane invaginations and cytoplasmic vesicles are signs of an endocytic mechanism. Moreover, Hussain and coworkers showed that macropynocitosis was involved in $16 \mathrm{HBE}$ internalisation of the same CB MNP than those used in the present study (Hussain et al., 2009). We did not find MNPs in the mitochondria or nuclei, in agreement with studies by Xia et al. (2006) and Bhattacharya et al. (2009). However, in other studies that used primary human monocyte macrophages or mesenchymal stem cells, MNPs were found in these compartments (Hackenberg et al., 2011; Porter et al., 2006), suggesting that the site of accumulation may depend on the MNP type and/or cell type. Overall, the data reported here suggest that MNPs may accumulate similarly in lung epithelial cells and fibroblasts.

We evaluated the influence of MNP physico-chemical characteristics on intracellular accumulation. We focused on MNP with a narrow range of diameters (13-21 nm), but differences in chemical composition $\left(\mathrm{TiO}_{2}\right.$ vs. $\left.\mathrm{CB}\right)$, and specific surface area (CB13 vs. CB21). Both $\mathrm{TiO}_{2}$ and CB MNPs accumulated rapidly, in keeping with earlier studies in several lung models showing accumulation after only 6h (Geiser et al., 2005; Stearns et al., 2001). For example, a flow cytometry study reported in 2011 showed that internalisation of $\mathrm{SiO}_{2}$ MNPs measuring 50 to $300 \mathrm{~nm}$ by the alveolar epithelial cell line A549 cells occurred chiefly within the first 2 hours and reached a plateau after 6 hours (Shapero et al., 2011). The percentage of cells containing MNPs was similar with the 3 MNP types, all of which were 
visible as aggregates surrounded by a membrane, and, rarely, as isolated particles. Aggregates may reflect internalisation of isolated MNPs and/or of MNP aggregates. The granulometric evaluation of MNPs in the culture media strongly supports the second possibility, since all 3 MNP types were detected as aggregates measuring about $1 \mu \mathrm{m}$ in diameter. Furthermore, it has been shown that non-phagocytic cells internalise MNP aggregates more easily than isolated MNPs (Andersson et al., 2011; Hackenberg et al., 2011). Therefore, the cells probably internalised the MNPs chiefly as aggregates. The mean size of MNP aggregate within cells, as determined using TEM to evaluate sections, seemed to be smaller (about $0.1 \mu \mathrm{m}^{2}$ ) than the mean diameter of aggregates in culture medium, as determined using PCS. If the particles have a round-like shape, then the aggregate size in the culture medium should be greater than $0.8 \mu \mathrm{m}^{2}$, and MRC5 and $16 \mathrm{HBE}$ cells may unable to internalize the largest aggregates. However, these considerations must be viewed with caution because we compared a measured aggregate size within cells (obtained using TEM) to a calculated aggregate size in the culture medium. Overall, our results suggest that the chemical nature and specific surface area of the 3 MNPs influenced neither the kinetics of MNP internalisation nor the percentage of cells containing accumulated MNPs. Furthermore, all 3 MNP were found as aggregates within cells.

Internalised $\mathrm{TiO}_{2}$ MNPs behaved differently from accumulated CB MNPs. Thus, the size of intracellular $\mathrm{TiO}_{2}$ MNP aggregates was higher overall than that of the CB MNP aggregates. This different was seen with both cell types, starting at $6 \mathrm{~h}$ and with the lowest dosages. This result suggests that $\mathrm{TiO}_{2}$ MNPs may penetrate the cell and accumulate in a single vesicle that is constantly full. Pan et al. (2009) obtained similar results using primary dermal fibroblasts incubated with rutile $\mathrm{TiO}_{2}$ MNPs. However, they also observed that anatase particles produced huge holes in the cell cytoplasm, a finding not replicated in our study. MNP size was similar in the study by Pan et al. (2009) and in our study, but the discrepancy may be related to other differences in the experimental conditions (e.g., presence $v s$. absence of serum in the culture media with the MNPs and primary $v s$. fibroblastic cell line). Since the 3 MNPs used in our study were closely similar in size and shape, these 2 parameters were probably not involved in the difference between $\mathrm{TiO}_{2}$ and CB MNPs. A role for the specific surface area of the MNPs (Hsiao et al., 2011; Yue et al., 2010 ) is unlikely since this parameter was similar for the $\mathrm{TiO}_{2}$ and $\mathrm{CB} 21 \mathrm{MNPs}$. Furthermore, specific surface area was greater for the CB13 MNPs than for the CB21 MNPs, whereas the size of the intracellular aggregates was similar for these 2 MNPs. The chemical nature of the MNPs may affect the capacity for aggregation, leading to differences in intracellular behaviour. There is evidence that $\mathrm{TiO}_{2}$ MNPs form aggregates easily and rapidly in 
(hydrophilic) polar environments such as culture media (Geiser et al., 2005). The zeta potential data showing that $\mathrm{TiO}_{2}$ MNPs in DMEM had the lowest aggregation capacity and the smaller size of the $\mathrm{TiO}_{2}$ MNP aggregates compared to the CB21 MNP aggregates argue against this possibility. Another possibility is disaggregation of CB MNPs within cells, leading to a smaller size compared to $\mathrm{TiO}_{2} \mathrm{MNP}$ aggregates. Although data supporting this hypothesis was observed in MRC5 cells between 24 and 48h (fig. 5A), a similar phenomenon was observed concerning $\mathrm{TiO}_{2}$ aggregates, thus ruling out this hypothesis. Further work is needed to explain the difference in aggregate size between $\mathrm{TiO}_{2} \mathrm{MNPs}$ and CB MNPs.

We evaluated MNP cytotoxicity by performing the WST-1 assay on MNP-exposed cells. Of the 3 MNP types, only CB13 induced a decrease in MRC5 cellular viability. None of the 3 MNP types affected the viability of $16 \mathrm{HBE}$ cells. These results suggest that 1 ) internalised MNPs do not always exert cytotoxic effects such as those described in murine macrophages exposed to gold nanoparticles (Zhang et al., 2010), and that 2) the biological responses induced by MNP depend on the cell type. Inversely, we demonstrated previously that carbon nanotubes induced cytotoxicity in epithelial cells in the absence of internalisation (Tabet et al., 2009). The relationship between intracellular accumulation and cellular responses such as inflammation remains to be investigated. Another remarkable fact is that CB13 MNPs, the only cytotoxic particles in our study, also had the highest specific surface area. This parameter seems to play a crucial role in the biological effects of CB13 MNPs. In vivo and in vitro biological responses such as oxidative stress or inflammation correlate closely with the specific surface area of particles such as CB or silica (Brown et al., 2001; Hussain et al., 2009; Stoeger et al., 2006; Waters et al., 2009). However, this parameter was unrelated to accumulation in our study, emphasising the complexity of MNP effects on cells.

\section{Conclusion}

In conclusion, we showed that MNPs were widely and rapidly internalised by bronchial cells and pulmonary fibroblasts. In both cell types, MNPs accumulated as aggregates in cytosolic vesicles and were absent from the mitochondria or nuclei. MNP accumulation was rapid, and dependent on exposure time or concentration. Overall, CB and $\mathrm{TiO}_{2}$ MNP had similar accumulation patterns, although $\mathrm{TiO}_{2}$ aggregates had a higher size than CB aggregates. Intracellular MNP accumulation was dissociated from cytotoxicity. These results shed new light on the interactions between MNPs and cells and indicate that internalisation is a relatively stereotyped cellular response to MNP exposure, at least in nonphagocytic cells. 


\section{Conflict of Interest statement}

The authors declare that there are no conflicts of interest.

\section{Acknowledgements}

This work was supported by the "Agence Nationale de la Recherche France" (Nanotox project, ANR N 05979-5 SET 024-01), by the Department of Paris, by the "Agence nationale de sécurité sanitaire de l'Alimentation, de l'Environnement et du Travail" for a PhD grant and funding of Esther Belade, and by the "ABIES" PhD program for a PhD grant of Lucie Armand.

\section{References}

Al-Rawi M., Diabaté S., Weiss C., 2011. Uptake and intracellular localization of submicron and nano-sized SiO(2) particles in HeLa cells. Arch Toxicol.

Andersson P.O., Lejon C., Ekstrand-Hammarström B., Akfur C., Ahlinder L., Bucht A., Osterlund L., 2011. Polymorph- and Size-Dependent Uptake and Toxicity of $\mathrm{TiO}(2)$ Nanoparticles in Living Lung Epithelial Cells. Small. 7, 514-23.

AshaRani P.V., Low Kah Mun G., Hande M.P., Valiyaveettil S., 2009. Cytotoxicity and genotoxicity of silver nanoparticles in human cells. ACS Nano. 3, 279-90.

Baan R., Straif K., Grosse Y., Secretan B., El Ghissassi F., Cogliano V., WHO International Agency for Research on Cancer Monograph Working Group, 2006. Carcinogenicity of carbon black, titanium dioxide, and talc. Lancet Oncol. 7, 295-6.

Bartneck M., Keul H.A., Singh S., Czaja K., Bornemann J., Bockstaller M., Moeller M., Zwadlo-Klarwasser G., Groll J., 2010. Rapid uptake of gold nanorods by primary human blood phagocytes and immunomodulatory effects of surface chemistry. ACS Nano. 4, 307386.

Bhattacharya K., Davoren M., Boertz J., Schins R.P., Hoffmann E., Dopp E., 2009. Titanium dioxide nanoparticles induce oxidative stress and DNA-adduct formation but not DNAbreakage in human lung cells. Part Fibre Toxicol. 6, 17.

Boczkowski J., Lanone S., 2007. Potential uses of carbon nanotubes in the medical field: how worried should patients be? Nanomedicine (Lond).2, 407-10. 
Brown D.M., Wilson M.R., MacNee W., Stone V., Donaldson K., 2001. Size-dependent proinflammatory effects of ultrafine polystyrene particles: a role for surface area and oxidative stress in the enhanced activity of ultrafines. Toxicol Appl Pharmacol. 175, 191-9.

Churg A., Stevens B., Wright J.L., 1998. Comparison of the uptake of fine and ultrafine $\mathrm{TiO}_{2}$ in a tracheal explant system. Am J Physiol. 274, L81-6.

Conner S.D., Schmid S.L., 2003. Regulated portals of entry into the cell. Nature. 422, 37-44.

Cozens A.L., Yezzi M.J., Kunzelmann K., Ohrui T., Chin L., Eng K., Finkbeiner W.E., Widdicombe J.H., Gruenert D.C., 1994. CFTR expression and chloride secretion in polarized immortal human bronchial epithelial cells. Am J Respir Cell Mol Biol. 10, 38-47.

Dombu C.Y., Kroubi M., Zibouche R., Matran R., Betbeder D., 2010. Characterization of endocytosis and exocytosis of cationic nanoparticles in airway epithelium cells. Nanotechnology. 21, 355102.

Donaldson K., Tran L., Jimenez L.A., Duffin R., Newby D.E., Mills N., MacNee W., Stone V., 2005. Combustion-derived nanoparticles: a review of their toxicology following inhalation exposure. Part Fibre Toxicol. 2, 10.

Ema M., Kobayashi N., Naya M., Hanai S., Nakanishi J., 2010. Reproductive and developmental toxicity studies of manufactured nanomaterials. Reprod Toxicol. 30, 343-52.

Faklaris O., Garrot D., Joshi V., Druon F., Boudou J.P., Sauvage T., Georges P., Curmi P.A., Treussart F., 2008. Detection of single photoluminescent diamond nanoparticles in cells and study of the internalisation pathway. Small. 4, 2236-9.

Faklaris O., Joshi V., Irinopoulou T., Tauc P., Sennour M., Girard H., Gesset C., Arnault J.C., Thorel A., Boudou J.P., Curmi P.A., Treussart F., 2009. Photoluminescent diamond nanoparticles for cell labeling: study of the uptake mechanism in mammalian cells. ACS Nano. 3, 3955-62.

Geiser M., Rothen-Rutishauser B., Kapp N., Schürch S., Kreyling W., Schulz H., Semmler M., Im Hof V., Heyder J., Gehr P., 2005. Ultrafine particles cross cellular membranes by nonphagocytic mechanisms in lungs and in cultured cells. Environ Health Perspect. 113, 1555-60.

Geiser M., Casaulta M., Kupferschmid B., Schulz H., Semmler-Behnke M., Kreyling W., 2008. The role of macrophages in the clearance of inhaled ultrafine titanium dioxide particles. 
Am J Respir Cell Mol Biol. 38, 371-6.

Geiser M., Kreyling W., 2010. Deposition and biokinetics of inhaled nanoparticles. Part Fibre Toxicol. 7, 2.

Gupta A.K., Gupta M., 2005. Synthesis and surface engineering of iron oxide nanoparticles for biomedical applications. Biomaterials. 26, 3995-4021.

Gupta A.K., Gupta M., 2005. Synthesis and surface engineering of iron oxide nanoparticles for biomedical applications. Biomaterials. 26, 3995-4021.

Hackenberg S., Scherzed A., Kessler M., Hummel S., Technau A., Froelich K., Ginzkey C., Koehler C., Hagen R., Kleinsasser N., 2011. Silver nanoparticles: evaluation of DNA damage, toxicity and functional impairment in human mesenchymal stem cells. Toxicol Lett. 201, 27-33.

Hackley V.A., Ferraris C.F., 2001. The use of nomenclature in dispersion science and technology. US Government Printing Office, National Institute of Standards and Technology, Special Publication, Washington DC, pp 960-963

Hsiao I.L., Huang Y.J., 2011. Effects of various physicochemical characteristics on the toxicities of $\mathrm{ZnO}$ and $\mathrm{TiO}_{2}$ nanoparticles toward human lung epithelial cells. Sci Total Environ. 409, 1219-28.

Hussain S., Boland S., Baeza-Squiban A., Hamel R., Thomassen L.C., Martens J.A., BillonGalland M.A., Fleury-Feith J., Moisan F., Pairon J.C., Marano F., 2009. Oxidative stress and proinflammatory effects of carbon black and titanium dioxide nanoparticles: role of particle surface area and internalized amount. Toxicology. 260, 142-9.

Hussain S., Thomassen L.C., Ferecatu I., Borot M.C., Andreau K., Martens J.A., Fleury J, Baeza-Squiban A., Marano F., Boland S., 2010. Carbon black and titanium dioxide nanoparticles elicit distinct apoptotic pathways in bronchial epithelial cells. Part Fibre Toxicol. 7, 10.

Jacobs J.P., Jones C.M., Baille J.P., 1970. Characteristics of a human diploid cell designated MRC-5. Nature. 227, 168-70.

Kreyling W.G., Semmler M., Erbe F., Mayer P., Takenaka S., Schulz H., Oberdörster G., Ziesenis A., 2002. Translocation of ultrafine insoluble iridium particles from lung epithelium to 
extrapulmonary organs is size dependent but very low. J Toxicol Environ Health A. 65, 151330 .

L'Azou B., Jorly J., On D., Sellier E., Moisan F., Fleury-Feith J., Cambar J., Brochard P., Ohayon-Courtès C., 2008. In vitro effects of nanoparticles on renal cells. Part Fibre Toxicol. 5, 22.

Lanone S., Boczkowski J., 2006. Biomedical applications and potential health risks of nanomaterials: molecular mechanisms. Curr Mol Med. 6, 651-63.

Lanone S., Rogerieux F., Geys J., Dupont A., Maillot-Marechal E., Boczkowski J., Lacroix G., Hoet P., 2009. Comparative toxicity of 24 manufactured nanoparticles in human alveolar epithelial and macrophage cell lines. Part Fibre Toxicol. 6, 14.

Li N., Sioutas C., Cho A., Schmitz D., Misra C., Sempf J., Wang M., Oberley T., Froines J., Nel A., 2003. Ultrafine particulate pollutants induce oxidative stress and mitochondrial damage. Environ Health Perspect. 111, 455-60.

Liu R., Zhang X., Pu Y., Yin L., Li Y., Zhang X., Liang G., Li X., Zhang J., 2010. Small-sized titanium dioxide nanoparticles mediate immune toxicity in rat pulmonary alveolar macrophages in vivo. J Nanosci Nanotechnol. 10, 5161-9.

Moon C., Park H.J., Choi Y.H., Park E.M., Castranova V., Kang J.L., 2010. Pulmonary inflammation after intraperitoneal administration of ultrafine titanium dioxide (TiO2) at rest or in lungs primed with lipopolysaccharide. J Toxicol Environ Health A. 73, 396-409.

Mroz R.M., Schins R.P., Li H., Drost E.M., Macnee W., Donaldson K., 2007. Nanoparticle carbon black driven DNA damage induces growth arrest and AP-1 and NFkappaB DNA binding in lung epithelial A549 cell line. J Physiol Pharmacol. 58 Suppl 5, 461-70.

Mroz R.M., Schins R.P., Li H., Jimenez L.A., Drost E.M., Holownia A., MacNee W., Donaldson K., 2008. Nanoparticle-driven DNA damage mimics irradiation-related carcinogenesis pathways. Eur Respir J. 31, 241-51.

Nabeshi H., Yoshikawa T., Matsuyama K., Nakazato Y., Arimori A., Isobe M., Tochigi S., Kondoh S., Hirai T., Akase T., Yamashita T., Yamashita K., Yoshida T., Nagano K., Abe Y., Yoshioka Y., Kamada H., Imazawa T., Itoh N., Tsunoda S., Tsutsumi Y., 2010. Sizedependent cytotoxic effects of amorphous silica nanoparticles on Langerhans cells. Pharmazie. 65, 199-201. 
Nativo P., Prior I.A., Brust M., 2008. Uptake and intracellular fate of surface-modified gold nanoparticles. ACS Nano. 2, 1639-44.

Oberdörster G., Oberdörster E., Oberdörster J., 2005a. Nanotoxicology: an emerging discipline evolving from studies of ultrafine particles. Environ Health Perspect. 113, 823-39.

Oberdörster G., Maynard A., Donaldson K., Castranova V., Fitzpatrick J., Ausman K., Carter J., Karn B., Kreyling W., Lai D., Olin S., Monteiro-Riviere N., Warheit D., Yang H. and A report from the ILSI Research Foundation/Risk Science Institute Nanomaterial Toxicity Screening Working Group, 2005b. Principles for characterizing the potential human health effects from exposure to nanomaterials : elements of a screnning strategy. Part Fibre Toxicol. 2,8 .

Oh W.K., Kim S., Choi M., Kim C., Jeong Y.S., Cho B.R., Hahn J.S., Jang J., 2010. Cellular uptake, cytotoxicity, and innate immune response of silica-titania hollow nanoparticles based on size and surface functionality. ACS Nano. 4, 5301-13.

Pan Z., Lee W., Slutsky L., Clark R.A., Pernodet N., Rafailovich M.H., 2009. Adverse effects of titanium dioxide nanoparticles on human dermal fibroblasts and how to protect cells. Small. 5, 511-20.

Park E.J., Yi J., Chung K.H., Ryu D.Y., Choi J., Park K., 2008. Oxidative stress and apoptosis induced by titanium dioxide nanoparticles in cultured BEAS-2B cells. Toxicol Lett. 180, 222-9.

Porter A.E., Muller K., Skepper J., Midgley P., Welland M., 2006. Uptake of C60 by human monocyte macrophages, its localization and implications for toxicity: studied by high resolution electron microscopy and electron tomography. Acta Biomater. 2, 409-19.

Renwick L.C., Brown D., Clouter A., Donaldson K., 2004. Increased inflammation and altered macrophage chemotactic responses caused by two ultrafine particle types. Occup Environ Med. 61, 442-7.

Saxena R.K., Gilmour M.I., Hays M.D., 2008. Isolation and quantitative estimation of diesel exhaust and carbon black particles ingested by lung epithelial cells and alveolar macrophages in vitro. Biotechniques. 44, 799-805.

Schrand A.M., Schlager J.J., Dai L., Hussain S.M., 2010. Preparation of cells for assessing ultrastructural localization of nanoparticles with transmission electron microscopy. Nat 
Protoc. 5, 744-57.

Shapero K., Fenaroli F., Lynch I., Cottell D.C., Salvati A., Dawson K.A., 2011. Time and space resolved uptake study of silica nanoparticles by human cells. Mol Biosyst. 7, 371-8.

Singh S., Shi T., Duffin R., Albrecht C., van Berlo D., Höhr D., Fubini B., Martra G., Fenoglio I., Borm P.J., Schins R.P., 2007. Endocytosis, oxidative stress and IL-8 expression in human lung epithelial cells upon treatment with fine and ultrafine $\mathrm{TiO}_{2}$ : role of the specific surface area and of surface methylation of the particles. Toxicol Appl Pharmacol. 222, 141-51.

Stearns R.C., Paulauskis J.D., Godleski J.J., 2001. Endocytosis of ultrafine particles by A549 cells. Am J Respir Cell Mol Biol. 24, 108-115.

Stoeger T., Reinhard C., Takenaka S., Schroeppel A., Karg E., Ritter B., Heyder J., Schulz $\mathrm{H} ., 2006$. Instillation of six different ultrafine carbon particles indicates a surface area threshold dose for acute lung inflammation in mice. Environ Health Perspect. 114, 328-33.

Stone V., Johnston H., Clift M.J., 2007. Air pollution, ultrafine and nanoparticle toxicology: cellular and molecular interactions. IEEE Trans Nanobioscience. 6, 331-40.

Su Y., Xu J.Y., Shen P., Li J., Wang L., Li Q., Li W., Xu G.T., Fan C., Huang Q., 2010.

Cellular uptake and cytotoxic evaluation of fullerenol in different cell lines. Toxicology. 269, 155-9.

Tabet L., Bussy C., Amara N., Setyan A., Grodet A., Rossi M.J., Pairon J.C., Boczkowski J., Lanone S., 2009. Adverse effects of industrial multiwalled carbon nanotubes on human pulmonary cells. J Toxicol Environ Health A. 72, 60-73.

Thurn K.T., Arora H., Paunesku T., Wu A., Brown E.M., Doty C., Kremer J., Woloschak G., 2010. Endocytosis of titanium dioxide nanoparticles in prostate cancer PC-3M cells.

Nanomedicine. 7, 123-30

Trono J.D., Mizuno K., Yusa N., Matsukawa T., Yokoyama K., Uesaka M., 2011. Size, Concentration and Incubation Time Dependence of Gold Nanoparticle Uptake into Pancreas Cancer Cells and its Future Application to X-ray Drug Delivery System. J Radiat Res. 52, 103-9.

Trouiller B., Reliene R., Westbrook A., Solaimani P., Schiestl R.H., 2009. Titanium dioxide nanoparticles induce DNA damage and genetic instability in vivo in mice. Cancer Res. 69, 
8784-9.

Val S., Hussain S., Boland S., Hamel R., Baeza-Squiban A., Marano F., 2009. Carbon black and titanium dioxide nanoparticles induce pro-inflammatory responses in bronchial epithelial cells: need for multiparametric evaluation due to adsorption artifacts. Inhal Toxicol. 21 Suppl $1,115-22$.

Vanwinkle B.A., de Mesy Bentley K.L., Malecki J.M., Gunter K.K., Evans I.M., Elder A., Finkelstein J.N., Oberdörster G., Gunter T.E., 2009. Nanoparticle (NP) uptake by type I alveolar epithelial cells and their oxidant stress response. Nanotoxicology. 3, 307-318.

Waters K.M., Masiello L.M., Zangar R.C., Tarasevich B.J., Karin N.J., Quesenberry R.D., Bandyopadhyay S., Teeguarden J.G., Pounds J.G., Thrall B.D., 2009. Macrophage responses to silica nanoparticles are highly conserved across particle sizes. Toxicol Sci. 107, 553-69.

Win K.Y., Feng S.S., 2005. Effects of particle size and surface coating on cellular uptake of polymeric nanoparticles for oral delivery of anticancer drugs. Biomaterials. 26, 2713-22.

Xia T., Kovochich M., Brant J., Hotze M., Sempf J., Oberley T., Sioutas C., Yeh J.I., Wiesner M.R., Nel A.E., 2006. Comparison of the abilities of ambient and manufactured nanoparticles to induce cellular toxicity according to an oxidative stress paradigm. Nano Lett. $6,1794-807$.

Yue H., Wei W., Yue Z., Lv P., Wang L., Ma G., Su Z., 2010. Particle size affects the cellular response in macrophages. Eur J Pharm Sci. 41, 650-7.

Zhang Q., Hitchins V.M., Schrand A.M., Hussain S.M., Goering P.L., 2010. Uptake of gold nanoparticles in murine macrophage cells without cytotoxicity or production of proinflammatory mediators. Nanotoxicology.

Zhao J., Bowman L., Zhang X., Vallyathan V., Young S.H., Castranova V., Ding M., 2009. Titanium dioxide $\left(\mathrm{TiO}_{2}\right)$ nanoparticles induce $\mathrm{JB} 6$ cell apoptosis through activation of the caspase-8/Bid and mitochondrial pathways. J Toxicol Environ Health A. 72, 1141-9.

Zucker R.M., Massaro E.J., Sanders K.M., Degn L.L., Boyes W.K., 2010. Detection of $\mathrm{TiO}_{2}$ nanoparticles in cells by flow cytometry. Cytometry A. 77, 677-85. 


\begin{tabular}{|c|c|c|c|c|c|c|c|c|c|}
\hline \multicolumn{5}{|c|}{ Provider data } & \multicolumn{5}{|c|}{ Data from the physico-chemical characterisation study } \\
\hline & $\begin{array}{c}\text { Primary } \\
\text { particle } \\
\text { size } \\
\text { (nm) }\end{array}$ & Shape & $\begin{array}{c}\text { Crystalline } \\
\text { phase }\end{array}$ & $\begin{array}{c}\text { Purity } \\
\text { (\%) }\end{array}$ & $\begin{array}{c}\text { Specific } \\
\text { surface } \\
\text { area } \\
\left(\mathrm{m}^{2} / g\right)\end{array}$ & $\begin{array}{c}\text { Zeta } \\
\text { potential } \\
\text { (mV) }\end{array}$ & $\begin{array}{c}\text { Granulometry } \\
\text { (nm) }\end{array}$ & $\begin{array}{c}\text { Endotoxin } \\
\text { (U/ml) }\end{array}$ & Provider \\
\hline \multicolumn{10}{|c|}{ Carbon black } \\
\hline CB13 & 13 & round & - & 99 & $\begin{array}{c}373.1 \\
\pm 10.5\end{array}$ & -11.9 & $\begin{array}{l}1033,4 \\
\pm 88,1\end{array}$ & nd & $\begin{array}{l}\text { Evonik/ } \\
\text { Degussa }\end{array}$ \\
\hline CB21 & 21 & round & - & 99 & $\begin{array}{l}106.2 \\
\pm 0.8\end{array}$ & -10.8 & $\begin{array}{r}1573,8 \\
\pm 175,6\end{array}$ & nd & $\begin{array}{l}\text { Evonik/ } \\
\text { Degussa }\end{array}$ \\
\hline \multicolumn{10}{|c|}{ Titanium dioxide } \\
\hline $\mathrm{TiO}_{2}$ & 15 & round & anatase & 99.7 & $\begin{array}{l}140.9 \\
\pm 3.3\end{array}$ & -0.1 & $\begin{array}{c}833,7 \\
\pm 38,6 *\end{array}$ & nd & $\begin{array}{l}\text { Sigma- } \\
\text { Aldrich }\end{array}$ \\
\hline
\end{tabular}

Table 1. Physico-chemical characterisation of manufactured nanoparticles.

Zeta potential and granulometry were evaluated in DMEM without foetal bovine serum.

Corresponding data are presented as the mean \pm SEM. * Significantly different compared to CB21 $(p<0.05)$. nd $=$ not detected. 


\section{Figure Legends}

Fig. 1. Transmission electron microscopy views of MRC5 cells incubated with $5 \mu \mathrm{g} . \mathrm{cm}^{-2}$ of manufactured nanoparticles (MNPs) for 6 hours. (A) Typical MRC5 cell with CB13 MNPs within a vesicle (scale bars: $2 \mu \mathrm{m}$ on the left, $0.5 \mu \mathrm{m}$ on the right). (B) CB21 MNPs being internalised by a MRC5 cell (scale bars: $5 \mu \mathrm{m}$ on the left, $0.5 \mu \mathrm{m}$ on the right). (C) MRC5 cell with $\mathrm{TiO}_{2}$ MNPs in a vesicle (scale bars: $5 \mu \mathrm{m}$ on the left, $0.5 \mu \mathrm{m}$ on the right).

Fig. 2. Transmission electron microscopy views of $16 \mathrm{HBE}$ cells incubated with $5 \mu \mathrm{g} . \mathrm{cm}^{-2}$ of manufactured nanoparticles (MNPs) for 6 hours. (A) Typical 16HBE cell with CB13 MNPs in a vesicle (scale bars: $10 \mu \mathrm{m}$ on the left, $0.5 \mu \mathrm{m}$ on the right). (B) 16HBE cell with a vesicle containing CB21 MNPs (scale bars: $5 \mu \mathrm{m}$ on the left, $0.5 \mu \mathrm{m}$ on the right). (C) $16 \mathrm{HBE}$ cell with $\mathrm{TiO}_{2}$ MNPs in a vesicle (scale bars: $2 \mu \mathrm{m}$ on the left, $0.5 \mu \mathrm{m}$ on the right).

Fig. 3. Percentage of cells containing manufactured nanoparticles (MNPs). (A) MRC5 cells incubated with $5 \mu \mathrm{g} . \mathrm{cm}^{-2}$ of MNPs for $6 \mathrm{~h}, 24 \mathrm{~h}$, or $48 \mathrm{~h}$. (B) $16 \mathrm{HBE}$ cells incubated with $5 \mu \mathrm{g} . \mathrm{cm}^{-2}$ of MNPs for $6 \mathrm{~h}, 24 \mathrm{~h}$ or, $48 \mathrm{~h}$. (C) MRC5 cells incubated for $24 \mathrm{~h}$ with $0.5,5$, or $10 \mu \mathrm{g} . \mathrm{cm}^{-2}$ of MNPs. (D) $16 \mathrm{HBE}$ cells incubated for $24 \mathrm{~h}$ with $0.5,5$ or $10 \mu \mathrm{g} . \mathrm{cm}^{-2}$ of MNPs. The Figure displays the results of one representative experiment $(\mathrm{N}=50$ cells) of 3 independent experiments. * Significant difference across MNP types $(p<0.05)$. \# Significant difference between cell types $(p<0.05)$. Y axis: percentage of cells containing MNPs.

Fig. 4. Number of manufactured nanoparticles (MNPs) in cells. (A) MRC5 cells incubated with $5 \mu \mathrm{g} . \mathrm{cm}^{-2}$ of MNPs for $6 \mathrm{~h}, 24 \mathrm{~h}$, or $48 \mathrm{~h}$. (B) $16 \mathrm{HBE}$ cells incubated with $5 \mu \mathrm{g} . \mathrm{cm}^{-2}$ of MNPs for $6 \mathrm{~h}, 24 \mathrm{~h}$, or $48 \mathrm{~h}$. (C) MRC5 cells incubated for $24 \mathrm{~h}$ with $0.5,5$ or $10 \mu \mathrm{g} . \mathrm{cm}^{-2}$ of MNPs. (D) $16 \mathrm{HBE}$ cells incubated for $24 \mathrm{~h}$ with $0.5,5$ or $10 \mu \mathrm{g} . \mathrm{cm}^{-2}$ of MNPs. The Figure displays the results of one representative experiment ( $N=30-40$ cells) of 3 independent experiments. Data are mean \pm SEM. * Significant difference across MNP types $(p<0.05)$. \# Significant difference between cell types $(p<0.05)$. Y axis: number of MNPs in cells.

Fig. 5. Mean size of individual manufactured nanoparticles (MNPs) aggregates in cells. (A) MRC5 cells incubated with $5 \mu \mathrm{g} . \mathrm{cm}^{-2}$ of MNPs for $6 \mathrm{~h}, 24 \mathrm{~h}$, or $48 \mathrm{~h}$. (B) $16 \mathrm{HBE}$ cells incubated with $5 \mu \mathrm{g} . \mathrm{cm}^{-2}$ of MNPs for $6 \mathrm{~h}, 24 \mathrm{~h}$ or $48 \mathrm{~h}$. (C) MRC5 cells incubated for $24 \mathrm{~h}$ with $0.5,5$ or $10 \mu \mathrm{g} . \mathrm{cm}^{-2}$ of MNPs. (D) $16 \mathrm{HBE}$ cells incubated for $24 \mathrm{~h}$ with $0.5,5$ or $10 \mu \mathrm{g} . \mathrm{cm}^{-2}$ of MNPs. The Figure displays the results of one representative experiment ( $N=30-40$ cells) of 3 independent experiments. Data are mean \pm SEM. * Significant difference across MNPs $(p<0.05)$. \# Significant difference between cell types $(p<0.05)$. Y axis: mean size of individual MNP aggregates $\left(\mu \mathrm{m}^{2}\right)$. 
Fig. 6. Percentage of cell surface area occupied by manufactured nanoparticles (MNPs) aggregates. (A) MRC5 cells incubated with $5 \mu \mathrm{g} . \mathrm{cm}^{-2}$ of MNPs for $6 \mathrm{~h}, 24 \mathrm{~h}$ or $48 \mathrm{~h}$.

(B) $16 \mathrm{HBE}$ cells incubated with $5 \mu \mathrm{g} . \mathrm{cm}^{-2}$ of MNPs for $6 \mathrm{~h}$, $24 \mathrm{~h}$ or 48 hours. (C) MRC5 cells incubated for $24 \mathrm{~h}$ with $0.5,5$ or $10 \mu \mathrm{g} . \mathrm{cm}^{-2}$ of MNPs. (D) $16 \mathrm{HBE}$ cells incubated for $24 \mathrm{~h}$ with $0.5,5$ or $10 \mu \mathrm{g} . \mathrm{cm}^{-2}$ of MNPs. The Figure displays the results of one representative experiment ( $\mathrm{N}=30-40$ cells) of 3 independent experiments.. Data are mean \pm SEM.

* Significant difference across MNP types $(p<0.05)$. \# Significant difference between cell types $(p<0.05)$. Y axis: percentage of cell surface area occupied by MNP aggregates.

Fig. 7. Cytotoxicity of manufactured nanoparticles (MNPs) in MRC5 and 16HBE cells. Cells were exposed to $10 \mu \mathrm{g} . \mathrm{cm}^{-2}$ of MNPs for $24 \mathrm{~h}$. Cell viability was measured using the WST-1 assay. Data are the percentages of surviving cells relative to the control reported as the mean \pm SEM of three independent experiments. * Significantly different from control $(p<0.05)$. 
Figure 1

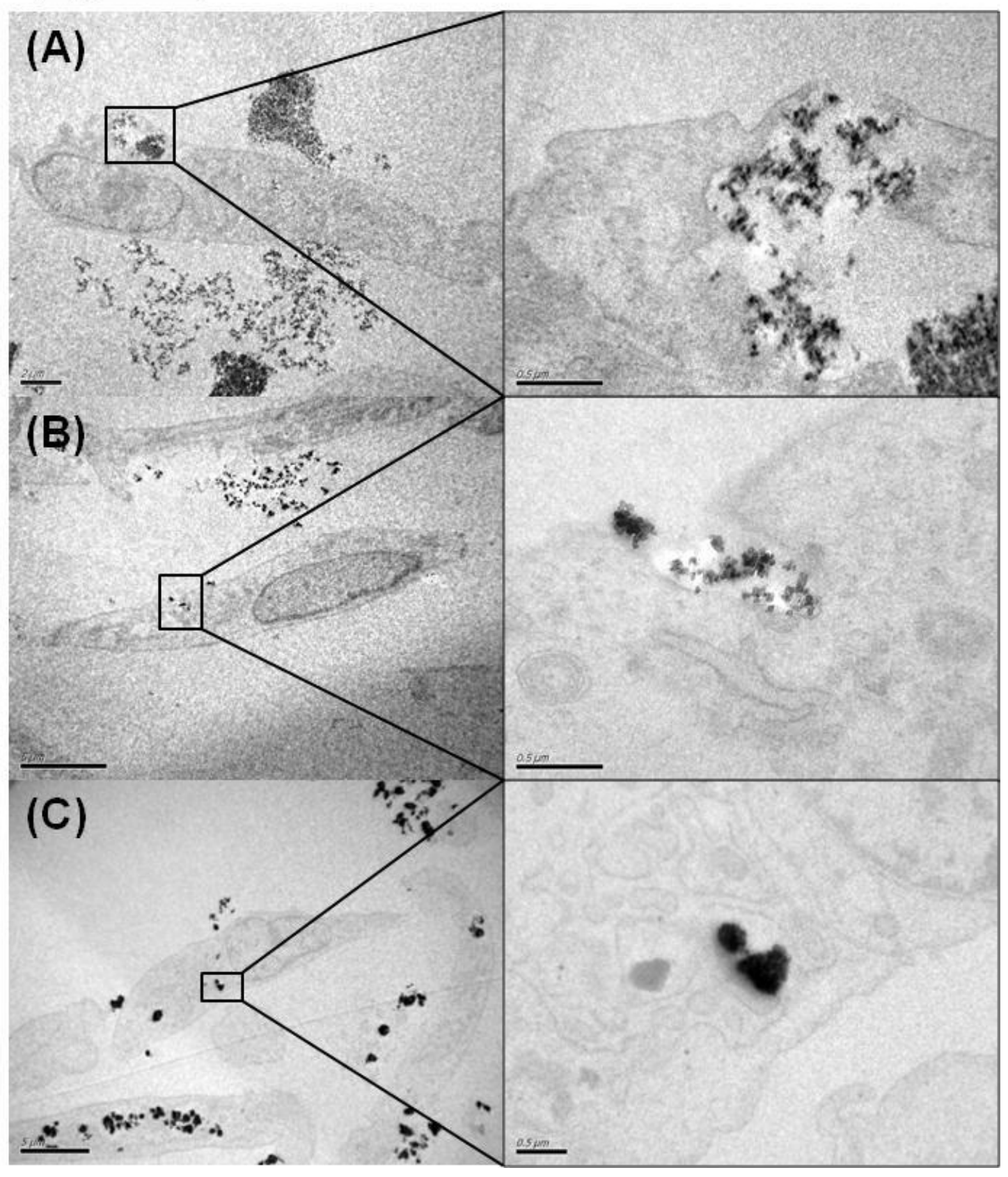


Figure 2

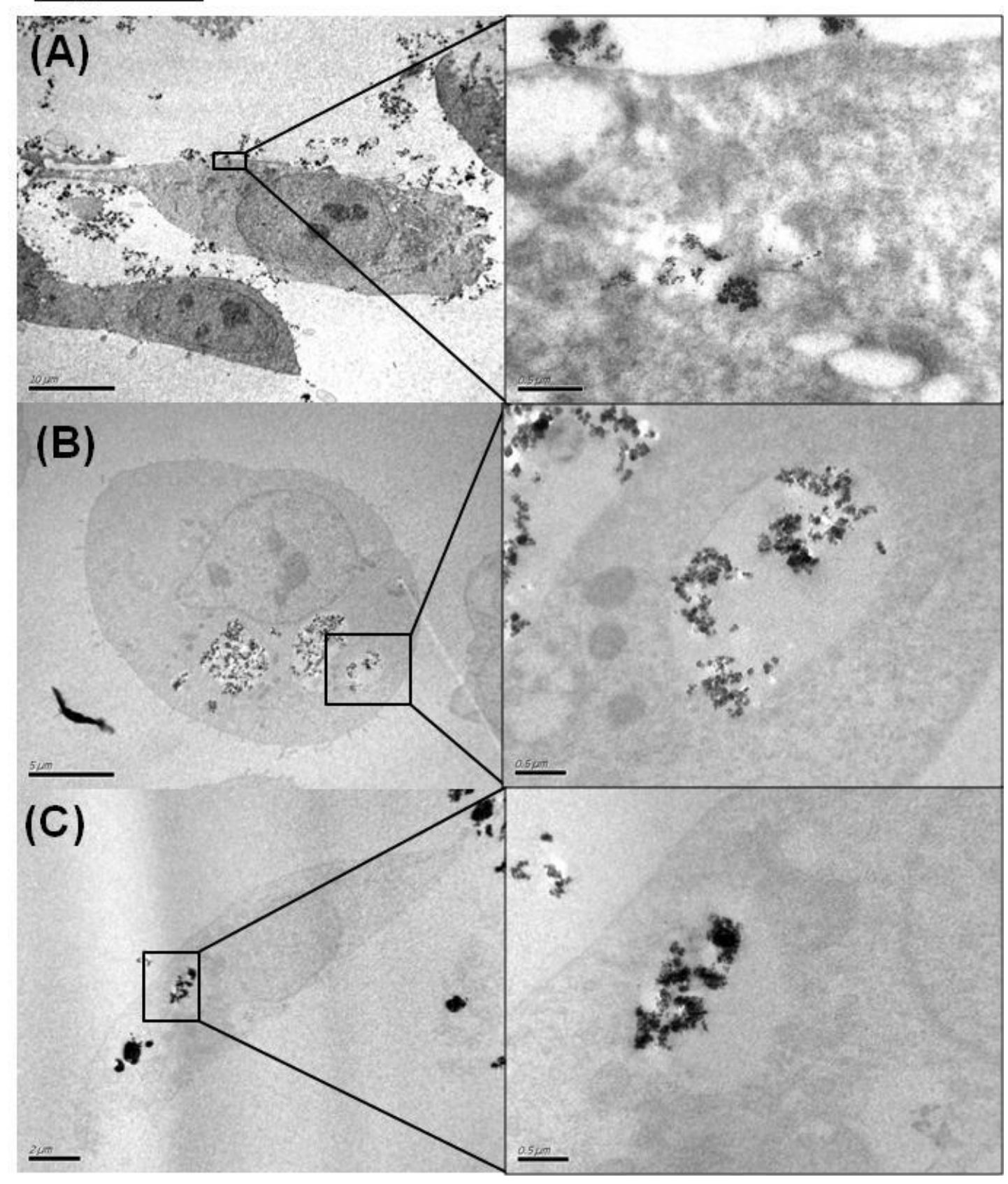




\section{Figure 3}

(A). MRC5 time-response relationship

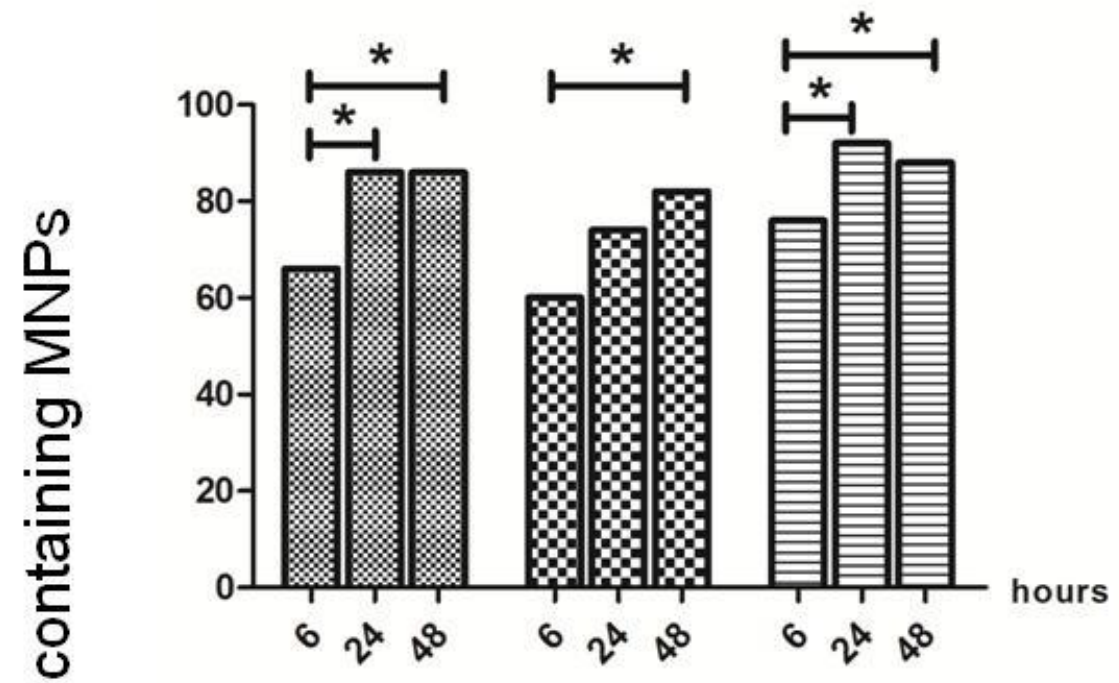

$\stackrel{(\Omega)}{\bar{N}} \quad$ (B). 16HBE time-response relationship

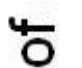

g

$\frac{\pi}{2}$
$\frac{0}{0}$
$\frac{0}{0}$
0

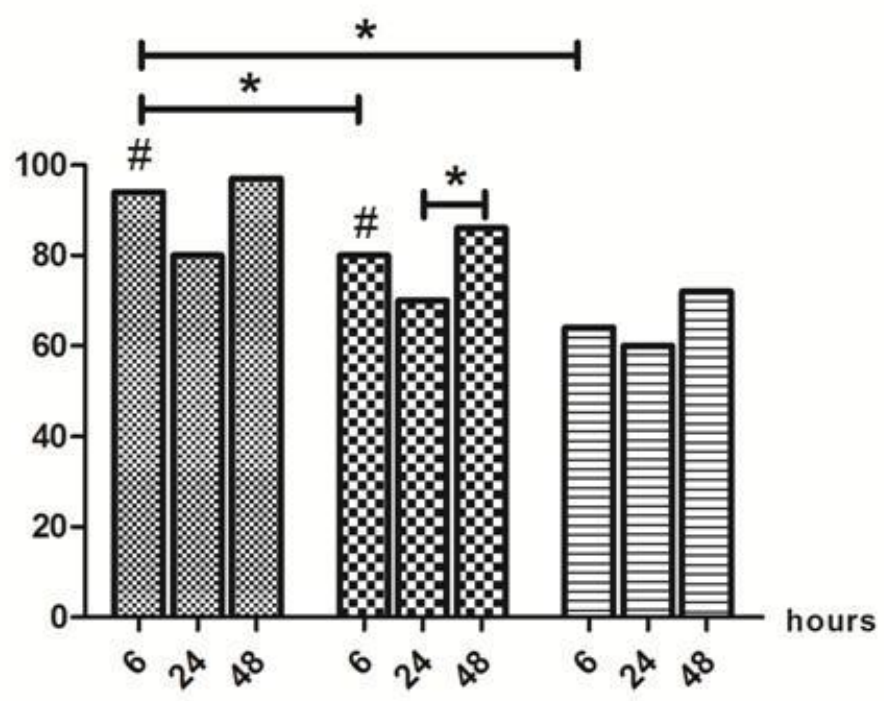

(C). MRC5 dose-response relationship

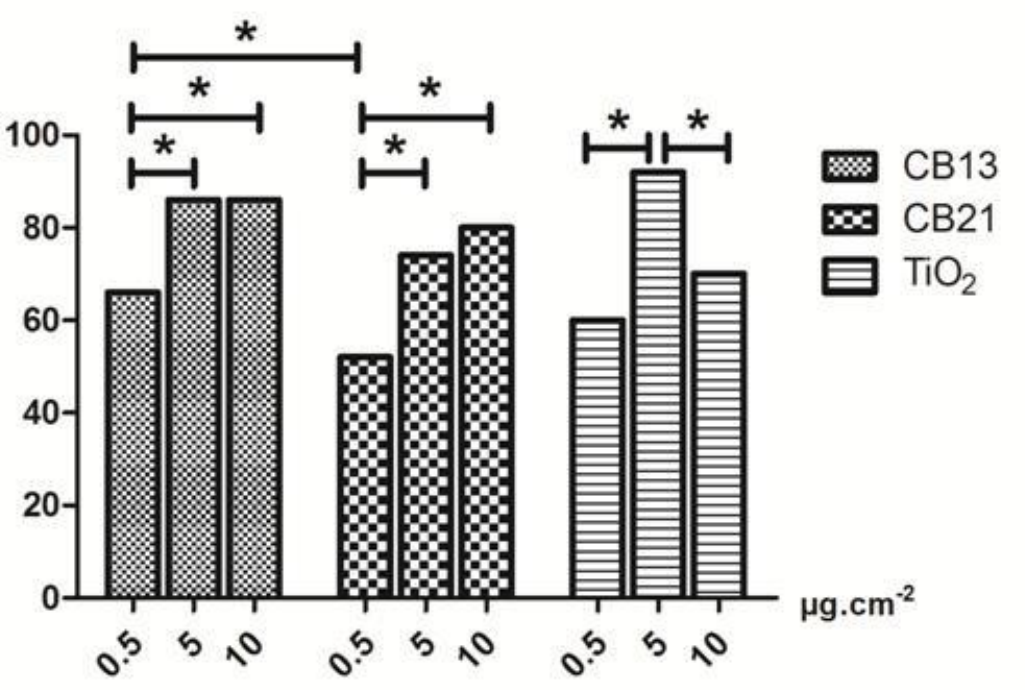

(D). 16HBE dose-response relationship

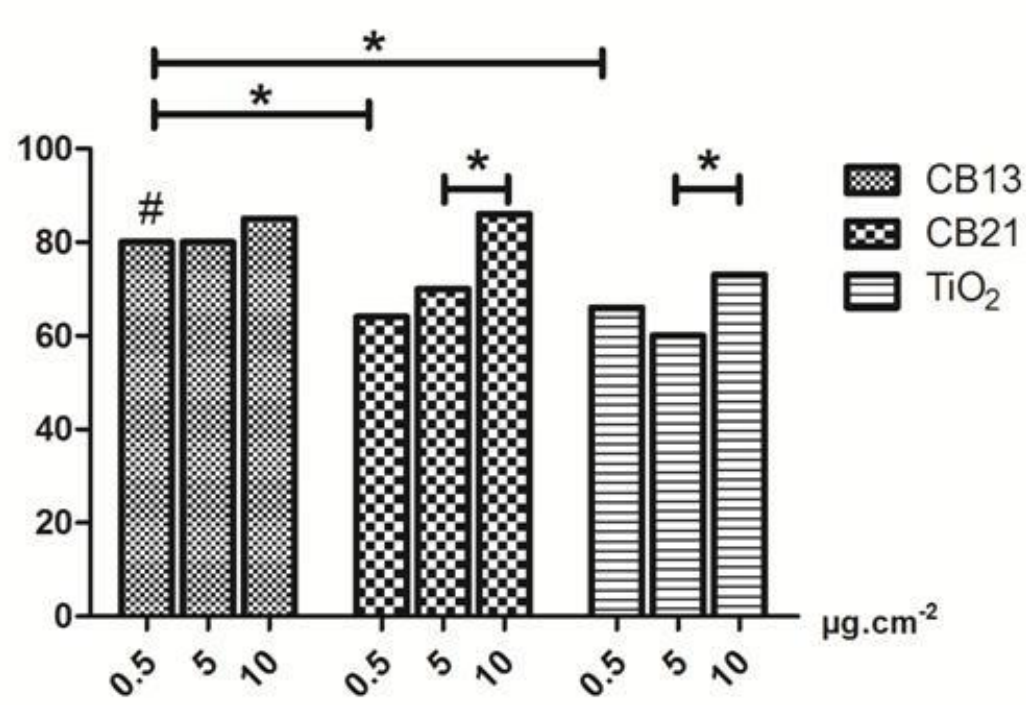


Figure 4

(A). MRC5 time-response relationship

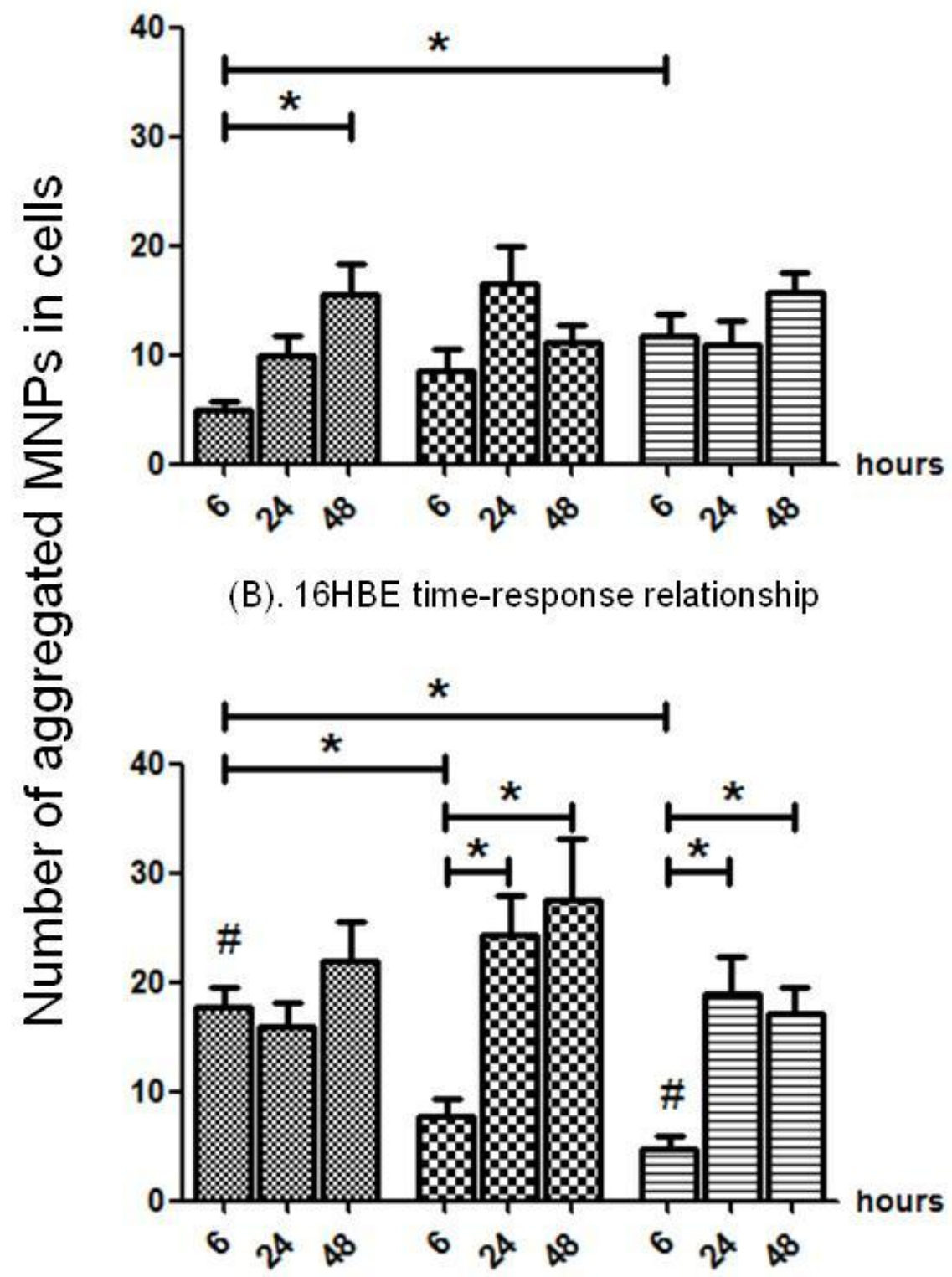

(C). MRC5 dose-response relationship
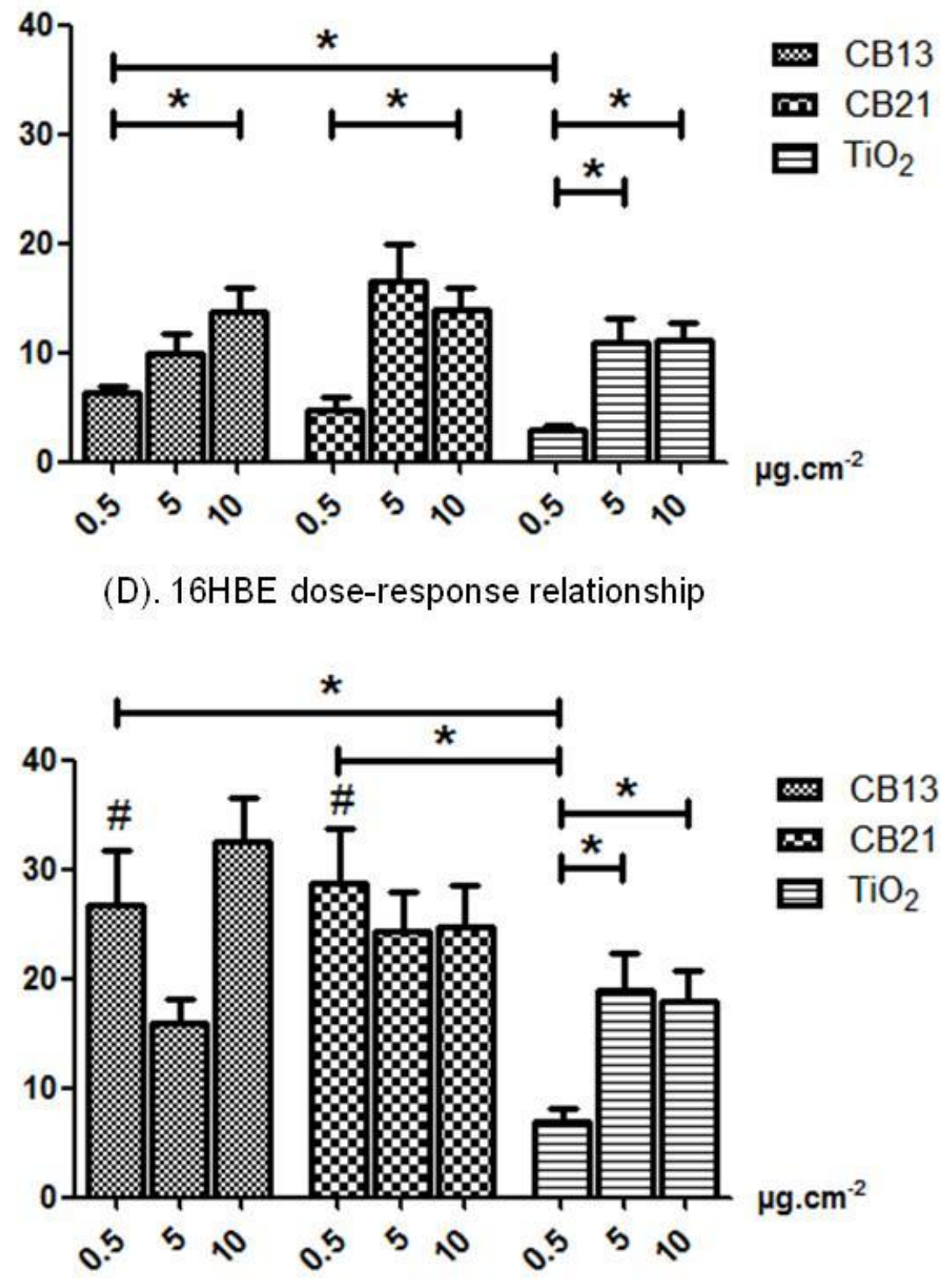


\section{Figure 5}

(A). MRC5 time-response relationship

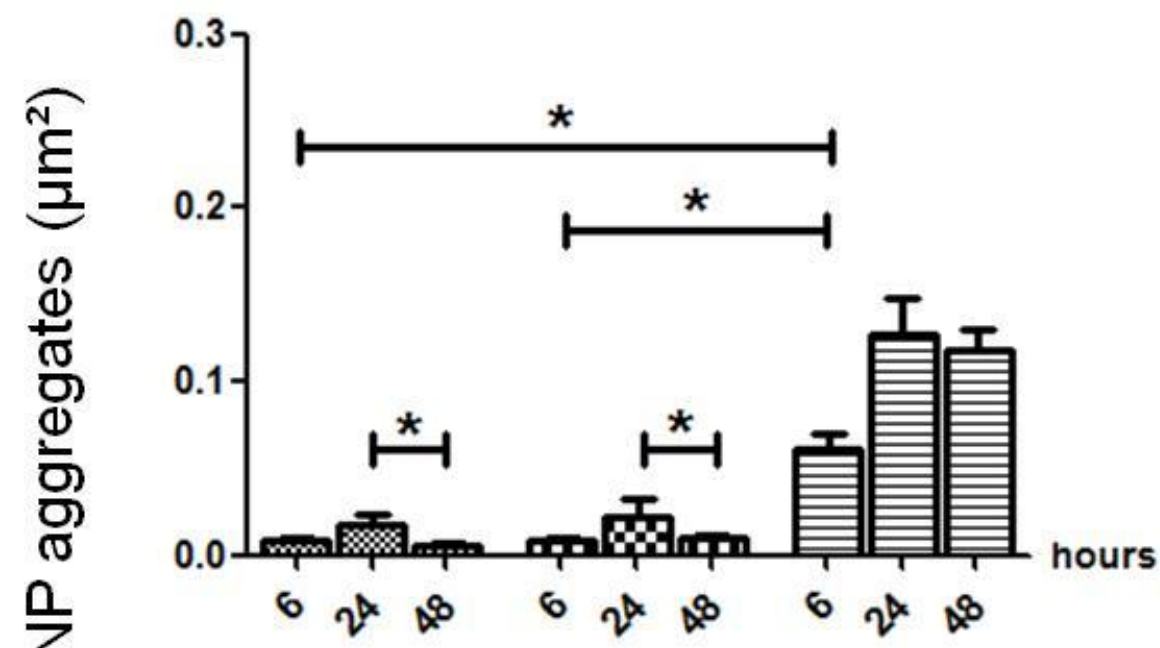

(B). 16HBE time-response relationship

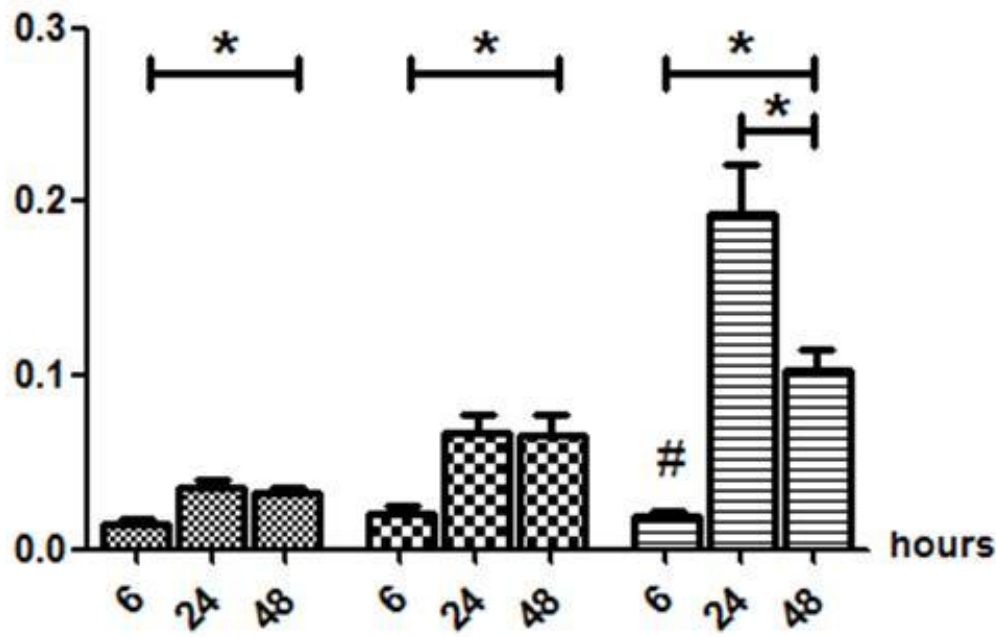

(C). MRC5 dose-response relationship

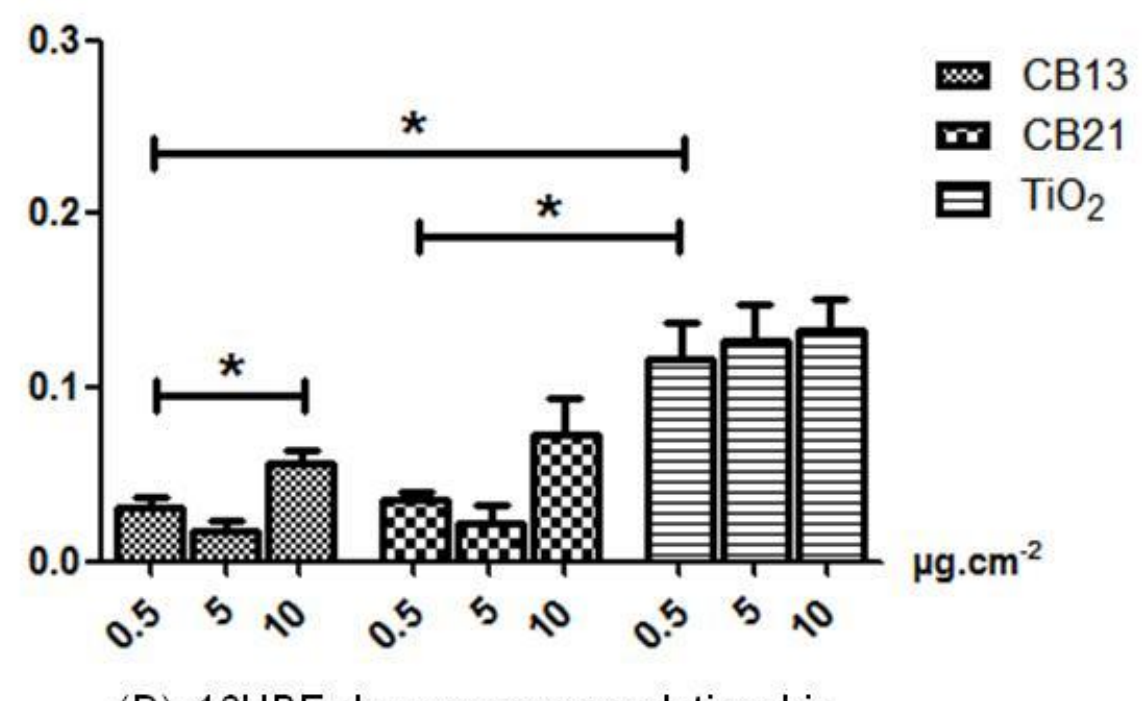

(D). 16HBE dose-response relationship

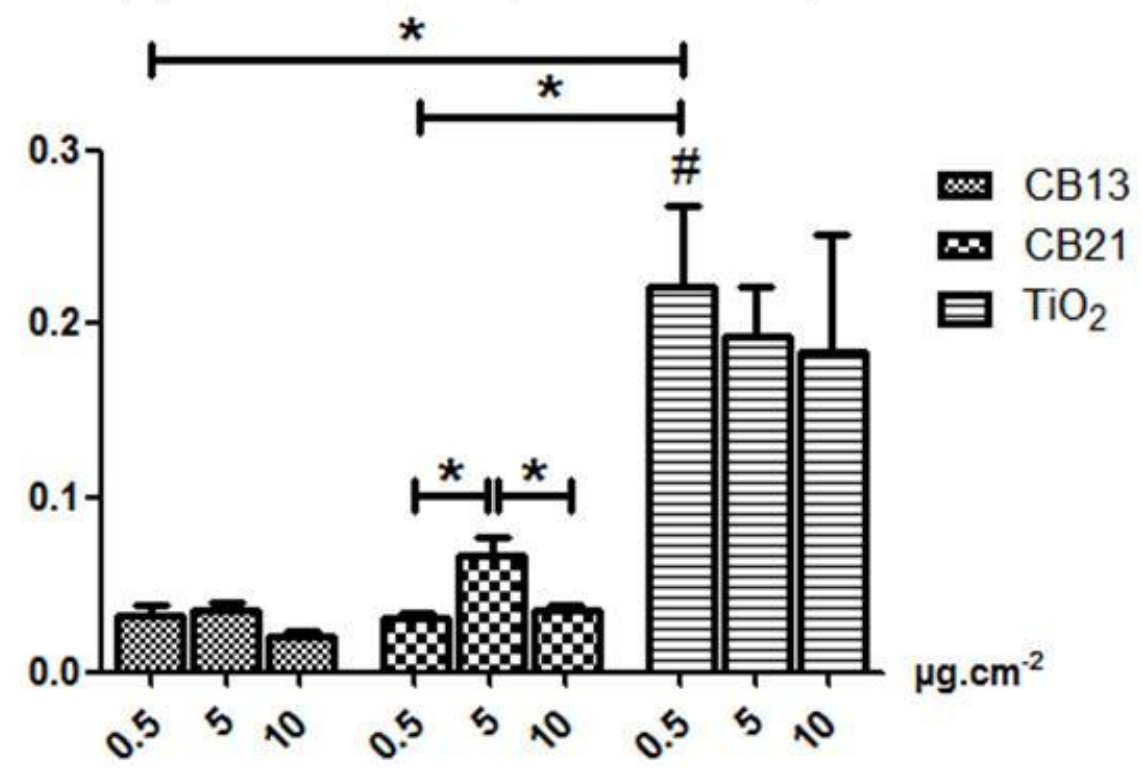




\section{Figure 6}

(C). MRC5 dose-response relationship
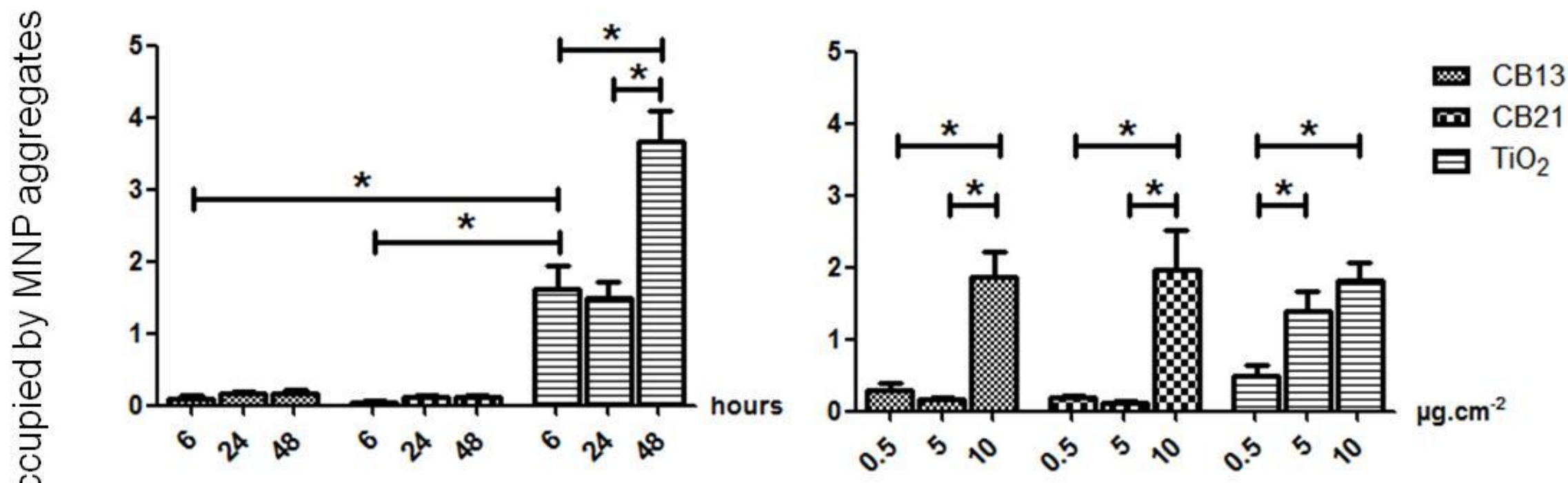

(B). 16HBE time-response relationship

(D). 16HBE dose-response relationship
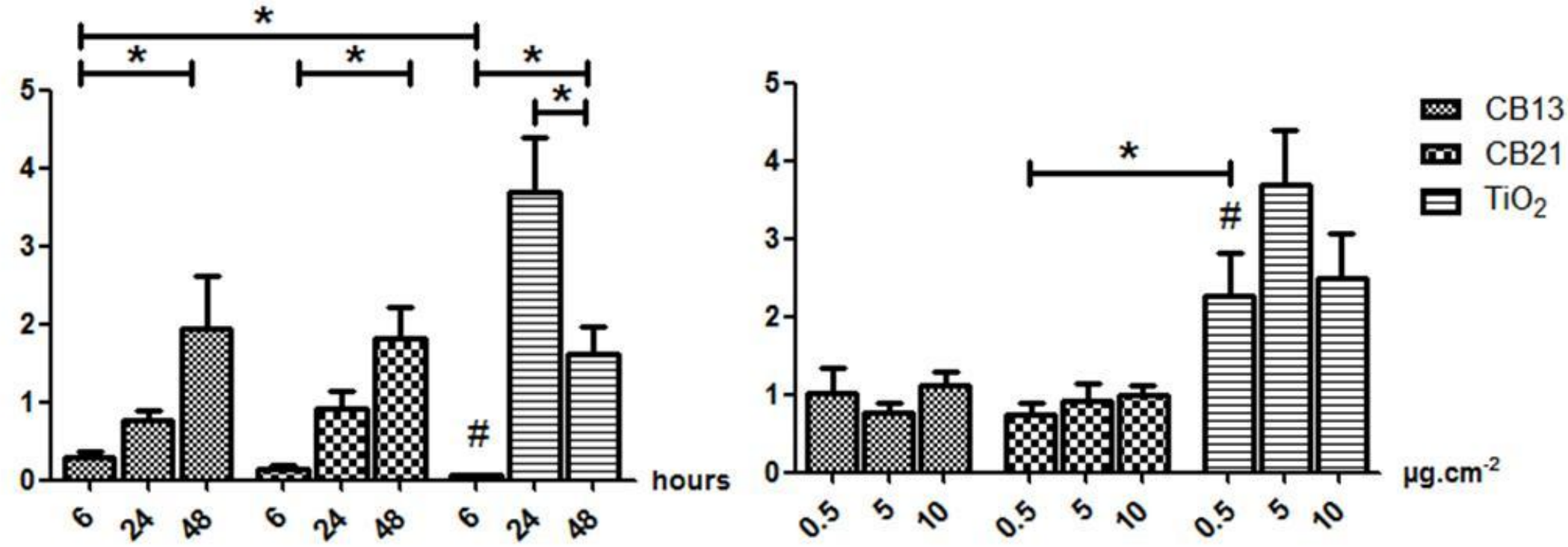


\section{Figure 7}

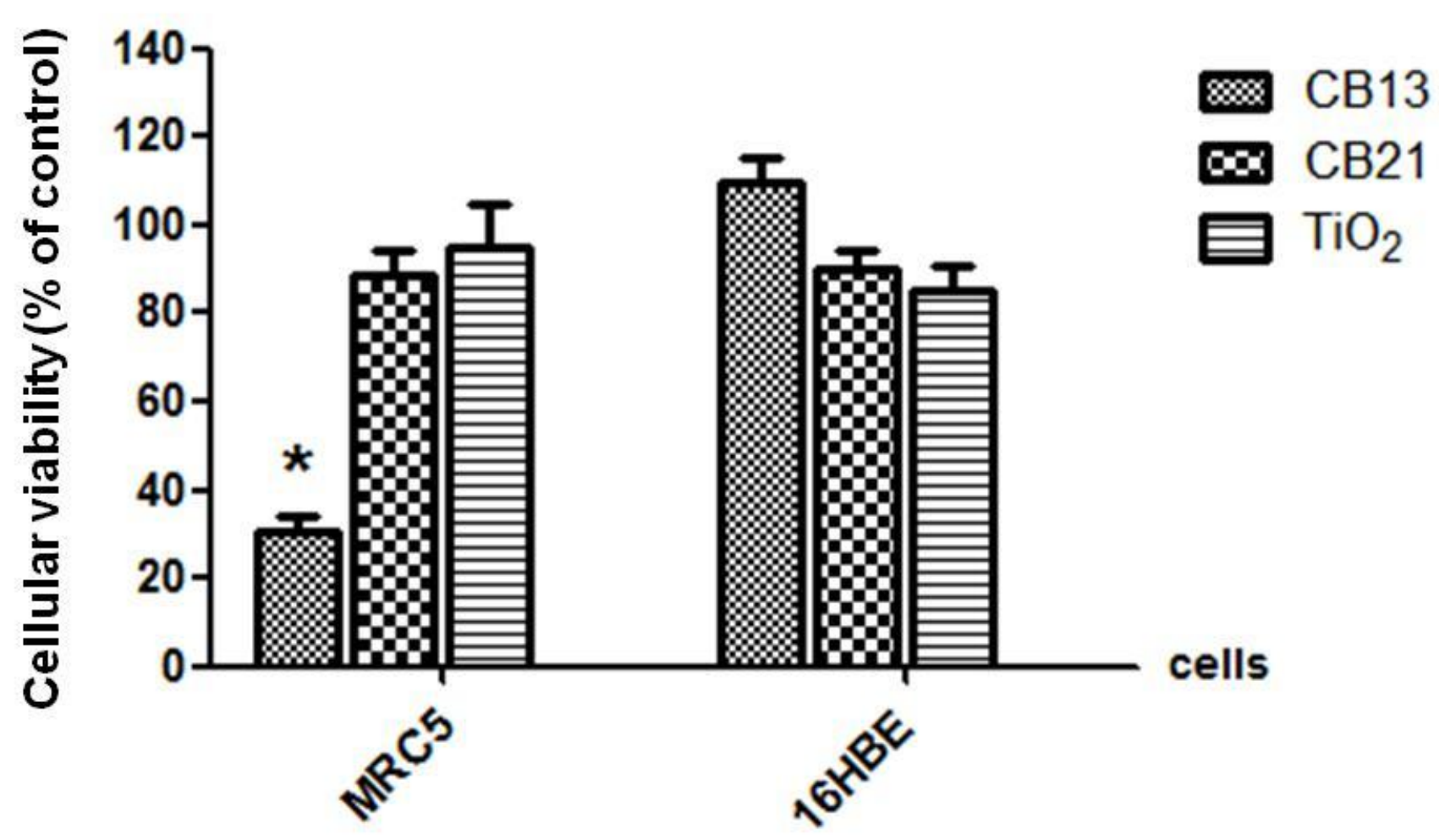

